\title{
All Work and No Pay: Establishing the Standard for When Legal, Unpaid Internships Become Illegal, Unpaid Labor
}

\section{Paul Budd}

\section{INTRODUCTION}

During the early twentieth century, working conditions in the United States were rough. Employees worked long hours under dangerous conditions and received very little pay. ${ }^{1}$ People used the term sweating to describe these difficult working conditions. ${ }^{2}$ Sweating is defined as "the unfair exploitation by unscrupulous employers of the necessities of the poorer and more helpless class of workers by requiring them to work for wages inadequate to their needs or for excessive hours or under insanitary conditions." "3 Today, while working conditions have improved for most, the term sweating could still be used to describe conditions for a certain type of worker - unpaid interns.

Abusive labor practices may not be as widespread or as visible as they were in the early twentieth century, but they are still a prevailing problem in the current intern labor market. Illegal unpaid internships subject a countless number of workers to "unfair exploitation by unscrupulous employers." The intern market is massive and so is the potential for abuse. In the United States, it is estimated there are between 1 to 2 million interns and as many as 50 percent of these interns

\footnotetext{
* Managing Editor, University of Kansas Law Review, Volume 63. J.D. Candidate, 2015, University of Kansas Law School; B.A., 2010, University of Minnesota-Duluth. I would like to thank Professor Joyce Rosenberg for taking an interest in my topic and providing me with valuable advice and feedback in developing my thesis. I would like to thank my friend Matthew Moriarty for taking the time to review my early drafts and helping me shape this into something worthy of being published. I would like to thank the Kansas Law Review board and staff for all of their hard work in reviewing this Comment. I would like to thank my wonderful girlfriend Lindsey for her support and encouragement, not only while writing this Comment, but throughout law school. Finally, I would like to thank the two most important people in my life, my mom and dad. Along with their love and support, they have given me every opportunity in life and I will always be grateful to them for that.

1. Willis J. Nordlund, The Quest for a Living Wage: The History of the Federal Minimum Wage Program 1-3 (1997).

2. $I d$. at 2 .

3. Id.

4. Id.
} 
may be unpaid. ${ }^{5}$ Of the roughly 1 million unpaid interns, it is unknown how many are actually misclassified employees performing illegal, unpaid labor for the benefit of an employer. This is unknown because of the high degree of legal uncertainty over what constitutes an internship. Until recently, this uncertainty was not apparent because internships had operated for decades without facing any serious legal challenges. ${ }^{6}$ However, in 2013, two cases in the U.S. Southern District of New York, Glatt v. Fox Searchlight Pictures Inc. ${ }^{7}$ and Xuedan Wang v. Hearst Corp. ${ }^{8}$ brought attention to the issue and led to an explosion of lawsuits filed by former interns against employers. ${ }^{9}$ In light of this recent litigation, courts cannot agree on what legal standard should apply to determine whether an intern should be classified as a trainee who is exempt from federal wage and hour requirements or as an employee who is entitled to wage and hour protections. Different courts have applied conflicting standards and the Department of Labor (DOL) has suggested its own standard. These conflicting standards have created uncertainty as to the legal status of internships. The longer this uncertainty lingers, the worse it is for employers, interns, employees, and the job market overall.

This Comment discusses the legal uncertainty over private sector internships and proposes the enactment of a clear, unambiguous regulatory provision to resolve the uncertainty. The Comment begins in Part II by discussing the background of federal wage laws and how they apply to interns. Next, it considers the different, conflicting standards courts are currently applying to unpaid internships. Part III offers a solution to the uncertainty by proposing that the DOL enact a regulatory provision that establishes a clear, unambiguous, all or nothing six-prong test for determining when an intern is exempt from federal wage and hour requirements.

5. Ross Perlin, Intern Nation: How To EARn Nothing AND LEARn LitTle in the BRaVe NEW ECONOMY 27-28 (2011). This estimate does not account for internships taken by community college students, graduate students, or recent graduates. Id.

6. Jeff P. Dunlaevy, "Research Me a Cup of Coffee and a Cinnamon Scone!" Unpaid Internships Pose Major Legal Risks, but Are Law Firms Exempt?, S.C. LAW, May 2014, at 44.

7. Glatt v. Fox Searchlight Pictures Inc., 293 F.R.D. 516 (S.D.N.Y. 2013), reh'g granted in part, No. 11 Civ. 6784 WHP, 2013 WL 4834428 (S.D.N.Y. Aug. 26, 2013), mot. to certify appeal granted, No. 11 Civ. 6784 WHP, 2013 WL 5405696 (S.D.N.Y. Sept. 17, 2013).

8. Xuedan Wang v. Hearst Corp., 293 F.R.D. 489 (S.D.N.Y. 2013), mot. to certify appeal granted, No. 12 CV 793 HB, 2013 WL 3326650 (S.D.N.Y. June 27, 2013).

9. See Internship Litigation Shows No Signs of Cooling, EMP'RS GUIDE TO THE FAIR LAB. STANDARDS ACT NEWSL. (Thompson Info. Servs.), July 2014, at 7 (discussing the flood of cases concerning unpaid interns and making suggestions on how employers should respond). 


\section{BACKGROUND}

To analyze and propose a solution that addresses the legal uncertainty over unpaid internships, the laws that are the source of the uncertainty must first be discussed. The Fair Labor Standards Act (FLSA) establishes mandatory minimum wage and maximum hour requirements for most employees in the United States. ${ }^{10}$ An unpaid private sector intern may be exempt from the FLSA's mandatory requirements if the intern is considered a trainee under the Supreme Court's trainee exception. ${ }^{11}$ However, courts are unsure what standard to apply when determining whether an unpaid intern is a trainee-creating legal uncertainty. ${ }^{12}$ The following section discusses the FLSA, ${ }^{13}$ how it applies to interns, ${ }^{14}$ and the inconsistent standards courts apply when determining whether unpaid interns are employees under the FLSA. ${ }^{15}$

\section{A. Federal Wage and Hour Laws}

1. Enactment of Minimum Wage and Maximum Hour Laws

Before the enactment of the FLSA in 1938, employees endured harsh conditions in the unregulated workforce. In Upton Sinclair's 1906 novel The Jungle, Sinclair focused on the abusive and grueling working conditions in the United States at the start of the twentieth century. ${ }^{16}$ In the novel, the main character Jurgis Rudkus worked at a slaughterhouse. ${ }^{17}$ Jurgis worked long hours and performed backbreaking labor in horrifying conditions. ${ }^{18}$ In addition to the terrible working conditions, Jurgis barely received enough in wages to survive. ${ }^{19}$ Because of the horrible working conditions and unsustainable wages, Jurgis eventually lost his home and family, ${ }^{20}$ became an alcoholic, ${ }^{21}$ and ended

10. 29 U.S.C. $\S \S 201-219$ (2012).

11. See Walling v. Portland Terminal Co., 330 U.S. 148, 153 (1947).

12. See infra Part II.B.3.

13. See infra Part II.A.

14. See infra Part II.B.

15. See infra Part II.B.3.

16. Upton Sinclair, The Jungle (Russ Castronovo ed., Oxford Univ. Press, Oxford World's Classics ed., 2010) (1906).

17. Id. passim.

18. Id. passim.

19. Id. at 98-99.

20. Id. at 169-72.

21. Id. passim. 
up living on the streets. ${ }^{22}$

While The Jungle is a work of fiction, its story is rooted in reality. During the early twentieth century, the economic concept of "sweating" drove the discussion for minimum wage legislation in the United States. $^{23}$ From 1923 to 1933 , there was increasing pressure by public interest groups to address the issue of sweating through legislative or judicial measures. ${ }^{24}$ At the time, one advocate for anti-sweating measures said, "[s]tarvation wages have come to be so prevalent that an insistent demand has again arisen for minimum wage legislation to put a stop to such ruthless exploitation . ...,25

Before the Great Depression, insufficient wages were a prevailing problem in the United States. When the Great Depression began in 1929, it significantly exacerbated the problem. For example, in 1929 the average weekly earnings for an individual working in the manufacturing industry was $\$ 25.03 .^{26}$ By 1933 that average had dropped to $\$ 16.73-\mathrm{a}$ staggering 33.2 percent decline in weekly earnings over a four-year period. $^{27}$

President Franklin D. Roosevelt addressed the issue in 1933 when he referred to the threat of persistently falling wages as "a serious form of unfair competition against other employers, reduc[ing] the purchasing power of the workers and threaten[ing] the stability of the industry." 28 To address the problem, President Roosevelt's Secretary of Labor, Frances Perkins, wrote a bill proposing minimum wage and maximum hour provisions for employees. ${ }^{29}$ In 1937, President Roosevelt sent the bill to Congress for a vote ${ }^{30}$ and endorsed the bill as a means to give "all our able-bodied working men and women a fair day's pay for a fair day's work." 31 After some back-and-forth in Congress, Congress eventually passed the bill and President Roosevelt signed it into law as the FLSA on

22. Id. at $212-13$.

23. See NordLund, supra note 1, at 2 (quoting Rudolf Broda, Minimum Wage Legislation in the United States, 17 INT'L LAB. REV. 24, 24 (1928)) (“[M]inimum wage legislation in the United States (1912) sprang from anti-sweating agitation.”).

24. Id. at $2-3$.

25. Id. at 3 .

26. Id. at 5 .

27. Id.

28. Id. at 3 .

29. Johnathan Grossman, Fair Labor Standards Act of 1938: Maximum Struggle for a Minimum Wage, U.S. DEP'T OF LABOR (June 1978), http://www.dol.gov/oasam/programs/history/flsa 1938.htm.

30. Id.

31. Id. 
June $25,1938 .^{32}$

Today, the FLSA provides minimum wage and maximum hour protections for employees in the United States. ${ }^{33}$ All employers who are subject to the FLSA must pay their employees a minimum wage of at least $\$ 7.25$ an hour. ${ }^{34}$ Furthermore, employers subject to the FLSA cannot require their employees to work more than forty hours a week unless they pay their employees one and one-half times their regular pay rate for every additional hour in excess of forty hours. ${ }^{35}$ Congress created the Wage and Hour Division as the regulatory agency tasked with enforcing the FLSA's minimum wage and maximum hour provisions. ${ }^{36}$ The Wage and Hour Division exists as a division within the larger DOL administrative agency. ${ }^{37}$ In addition to minimum wage and hour protections, the FLSA provides other protections for workers, such as prohibiting child labor and requiring equal pay. ${ }^{38}$

The FLSA's wage and hour provisions apply to private sector employers and their employees through the Commerce Clause. ${ }^{39}$ The provisions cover private employees engaged in interstate commerce or in the production of goods for interstate commerce, ${ }^{40}$ as well as private employees employed by an enterprise engaged in interstate commerce or in the production of goods for interstate commerce, with annual sales greater than $\$ 500,000 .^{41}$

The interstate commerce provisions of the FLSA create a very broad, far-reaching application of the FLSA to employer-employee relationships. Under the FLSA, work that consists of a purely local, isolated activity does not meet the FLSA's interstate commerce requirement; however, "[a]ny regular contact with commerce, no matter how small, will result in coverage."42 This minimal contact standard

32. $I d$.

33. 29 U.S.C. $\$ 206$ (2012).

34. 29 U.S.C. $\S 206(\mathrm{a})(1)(\mathrm{C})$.

35. 29 U.S.C. $\S 207(\mathrm{a})(1)$.

36. 29 U.S.C. $\$ 204$

37. $I d$.

38. See 29 U.S.C. $\S \S 212,206(d)$.

39. See Mark A. Rothstein et. Al., Employment Law 625 (4th ed. 2009) ("“T]he Supreme Court upheld the FLSA against commerce clause and due process attacks.").

40. 29 U.S.C. $\S \S 206(a), 207(a)(1)$.

41. 29 U.S.C. § 203(s)(1)(A)(i)-(ii); see also Padilla v. Manlapaz, 643 F. Supp. 2d 298, 299 (E.D.N.Y. 2009) ("These two distinct types of coverage are termed 'individual coverage' and 'enterprise coverage'....").

41. Williams v. Henagan, 595 F.3d 610, 621 (5th Cir. 2010) (quoting Sobrinio v. Med. Ctr. Visitor's Lodge, Inc., 474 F.3d 828, 829 (5th Cir. 2007)).

42. Williams v. Henagan, 595 F.3d 610, 621 (5th Cir. 2010) (quoting Sobrinio v. Med. Ctr. 
means the FLSA's requirements apply to the majority of private sector employers and employees in the United States. Furthermore, the FLSA is a remedial statute so the Supreme Court has held that any exemptions from the FLSA should be "narrowly construed against the employer.",43

While these commerce provisions extend the FLSA's wage and hour requirements to states, Congress has allowed states to establish their own minimum wage and maximum hour laws through the FLSA. ${ }^{44}$ A savings clause in the FLSA allows states to establish a minimum wage higher than the FLSA's mandated minimum wage and a maximum workweek lower than the FLSA's mandated maximum workweek. ${ }^{45}$ Therefore, if a state law creates minimum wage and maximum hour requirements that are more beneficial to employees than the FLSA's requirements, the state's requirements replace the FLSA's requirements; however, if the state law's requirements are less beneficial to employees, a conflict exists, and the FLSA preempts the state law. ${ }^{46}$ The conflict preemption only applies to private sector employer-employee relationships covered by the FLSA; however, most private sector employer-employee relationships are covered by the FLSA through the Commerce Clause. ${ }^{47}$

In addition to private employees, the FLSA also applies to public employees regardless of whether they are involved in interstate commerce. $^{48}$ The FLSA's definition of public employees includes individuals employed by the Government of the United States, ${ }^{49}$ individuals employed by the United States Postal Service, ${ }^{50}$ and certain individuals employed by a state. ${ }^{51}$ The FLSA's application to state and local government employees is fairly complex. ${ }^{52}$

Visitor's Lodge, Inc., 474 F.3d 828, 829 (5th Cir. 2007)).

43. Reich v. Gateway Press, Inc., 13 F.3d 685, 694 (3d. Cir. 1994) (citing Arnold v. Ben Kanowsky, Inc., 361 U.S. 388, 392 (1960)).

44. Daniel Dorris, Fair Labor Standards Act Preemption of State Wage-and-Hour Law Claims, 76 U. CHI. L. REV. 1251, 1255-56 (2009).

45. 29 U.S.C. $\$ 218$ (a) (2012).

46. See id. (providing that the law does not excuse non-compliance with another law that establishes a higher minimum wage or a lower maximum workweek); see also Baxter v. M.J.B. Investors, 876 P.2d 331, 336-37 (Or. Ct. App. 1994).

47. See Duke v. Birchfield, 222 F. Supp. 258, 261 (E.D. Okla. 1963) ("Commerce, as defined by Congress for the purpose of the Act, is a broad term ....").

48. See 29 U.S.C. § 203(d)-(e); Garcia v. San Antonio Metro. Transit Auth., 469 U.S. 528, 556-57 (1985) (stating that Congress's power to enforce wage and hour provisions under the FLSA on state agencies is not limited by the Commerce Clause).

49. 29 U.S.C. $\S 203(\mathrm{e})(2)(\mathrm{A})$.

50. 29 U.S.C. $\S 203(\mathrm{e})(2)(\mathrm{B})$.

51. 29 U.S.C. $\S 203(\mathrm{e})(2)(\mathrm{C})$.

52. Generally, private parties cannot enforce Commerce Clause-based statutes, such as the FLSA, against states in federal or state courts. However, federal agencies, such as the Department of 


\section{Employer-Employee Relationship under the FLSA}

For the FLSA's provisions to apply to an individual, the individual must be an employee under the FLSA. The FLSA defines employees as "any individual employed by an employer." 53 It defines employ as "to

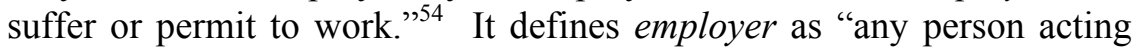
directly or indirectly in the interest of an employer in relation to an employee;", 55 and, a person is defined as "an individual, partnership, association, corporation, business trust, legal representative, or any organized group of persons. ${ }^{, 56}$ Therefore, an individual is an employee under the FLSA if an employer suffers the individual to work, or permits the individual to work, in the interest of the employer. If an individual wants to bring a claim under the FLSA, the individual must prove the existence of this employer-employee relationship. ${ }^{57}$

While this definition of an employer-employee relationship uses very broad, general terms, courts have shed some light on when an employeeemployer relationship exists under the FLSA. To determine whether an employer-employee relationship exists, courts look at the "economic reality" of the work relationship." ${ }^{58}$ Courts evaluate the economic reality of a work relationship on a case-by-case basis by considering relevant factors that may determine the nature of the relationship. ${ }^{59}$ As illustrated by the Second Circuit, the most important factor in determining the nature of the relationship is "control."60

The Second Circuit has said that an alleged employer's ability to control a worker is the key factor for determining whether the economic reality of the relationship is that of an employer-employee relationship. ${ }^{61}$ The Second Circuit uses two tests to determine whether an alleged

\footnotetext{
Labor, may enforce the FLSA's provisions against states and state agencies. ROTHSTEIN, supra note 39, at 664. Additionally, several amendments to the FLSA exempt certain state and local individuals from the definition of employee, so the FLSA does not apply to them. Id. at 664-69. This includes individuals performing "volunteer" service for state and local governments. Id. at 666 (referring to "volunteers" as defined under 29 U.S.C. § 203(e)(4)).

53. 29 U.S.C. $\$ 203(\mathrm{e})(1)$

54. 29 U.S.C. $\S 203(\mathrm{~g})$.

55. 29 U.S.C. $\S 203(d)$.

56. 29 U.S.C. § 203(a).

57. Urban v. Cont'l Convention \& Show Mgmt., 68 N.W.2d 633, 636 (Minn. 1955).

58. Barfield v. New York City Health \& Hosps. Corp., 537 F.3d 132, 141 (2d Cir. 2008) (quoting Goldberg v. Whitaker House Coop., Inc., 366 U.S. 28, 33 (1961)).

59. Id. at $141-42$.

60. See Herman v. RSR Sec. Servs. Ltd., 172 F.3d 132, 139 (2d Cir. 1999) (stating that the main concern in determining whether an individual is an employer is the "power to control the workers in question").

61. Id. at 135 .
} 
employer has control over a worker. The first test is the formal control test. $^{62}$ The formal control test considers four factors. The four factors are "whether the alleged employer (1) had the power to hire and fire the employees, (2) supervised and controlled employee work schedules or conditions of employment, (3) determined the rate and method of payment, and (4) maintained employment records."63 This test may show an alleged employer exercised enough formal control over a worker to establish employer status under the FLSA. ${ }^{64}$ If the formal control test does not show that an alleged employer had formal control over a worker, courts next consider whether an alleged employer had functional control over a worker, which may also establish employer status under the FLSA. ${ }^{65}$

The second test is a functional control test that considers factors that may show an alleged employer had sufficient functional control over a worker. $^{66}$ In the absence of formal control, functional control may establish employer status under the FLSA because the FLSA does not require absolute, formal control by an employer over an employee for an employer-employee relationship to exist. ${ }^{67}$ An employer-employee relationship may still exist under the FLSA even if the employer's control is restricted, nonobvious, or rarely exercised. ${ }^{68}$ The functional control test considers six factors to determine if functional control exists:

(1) whether [alleged employer's] premises and equipment were used for the plaintiffs' work; (2) whether the [alleged employer] had a business that could or did shift as a unit from one putative joint employer to another; (3) the extent to which plaintiffs performed a discrete line-job that was integral to [the alleged employer's] process of production; (4) whether responsibility under the contracts could pass from one subcontractor to another without material changes; (5) the degree to which the [alleged employer] or [its] agents supervised plaintiffs' work; and (6) whether plaintiffs worked exclusively or predominantly for [the alleged employer]. ${ }^{69}$

Together, the formal control test and the functional control test

62. Copantitla v. Fiskardo Estiatorio, Inc., 788 F. Supp. 2d 253, 308-09 (S.D.N.Y. 2011).

63. Id. at 308 (citation omitted).

64. Id. at $308-09$.

65. Id.

66. Id. at 309.

67. See Herman v. RSR Sec. Servs. Ltd., 172 F.3d 132, 139 (2d Cir. 1999) (stating that employer status does not require "continuous monitoring of employees, looking over their shoulders at all times, or any sort of absolute control of one's employees").

68. Id.

69. Copantitla, 788 F. Supp. 2d at 309 (citation omitted). 
provide courts with a set of overlapping factors to determine whether an alleged employer had enough control to qualify as an employer. ${ }^{70}$ While control is generally the most important factor courts consider, they may also consider other factors they think are relevant to determine whether an alleged employer is an actual employer under the FLSA. ${ }^{71}$

If employer status is established within the context of a work relationship, a worker's employee status will also likely exist. This is because the FLSA simply defines employee as "any individual employed by an employer." 72 Therefore, an FLSA employer-employee relationship is established almost exclusively by establishing employer status. ${ }^{73}$

While the FLSA extends wage and hour protections to employees who are "employed by an employer," to the term employee. Workers exempt from the FLSA's wage and hour requirements include students or trainees, ${ }^{75}$ independent contractors, ${ }^{76}$ volunteers, ${ }^{77}$ and some white-collar workers. ${ }^{78}$ For internships, the most significant exception is the student or "trainee" exception. The volunteer exception generally applies only to "public sector [organizations] or ... non-profit, non-commercial organizations."79 Therefore, the only way private, for-profit organizations may hire an intern without paying the

70. $I d$.

71. Id. See also RothSteIn, supra note 39, at 631 (discussing several factors, in addition to control, applied by courts to determine the economic reality of a work relationship, such as "... (2) the extent of the relative investments in equipment and material; (3) the worker's opportunity for profit and loss through managerial skill; (4) the skill initiative required by the work; (5) the permanence of the relationship; and (6) the extent to which the service rendered is an integral part of the alleged employer's business").

72. 29 U.S.C. $\S 203(\mathrm{e})(1)(2012)$. Within the definition of "employee," the term "employed" is not expressly defined, but "includes to suffer or permit to work." 29 U.S.C $§ 203(\mathrm{~g})$.

73. See e.g., Herman v. RSR Sec. Servs. Ltd., 172 F.3d 132, 135 (2d Cir. 1999) (stating that the employer's control is "central to deciding" whether the employer is liable to the employee under the FLSA for unpaid wages).

74. 29 U.S.C. $\S 203(\mathrm{e})(1)$.

75. RothSTEIN, supra note 39 , at 633-34 (listing six criteria that differentiate a trainee from an employee).

76. See id. at 631 (discussing the economic reality test used by courts to determine whether an individual is an employee or independent contractor).

77. 29 U.S.C. § 203(e)(4)-(5) (providing that, "[t]he term 'employee' does not include any individual who volunteers to perform services for a public agency" or "individuals who volunteer their services solely for humanitarian purposes to private non-profit food banks").

78. See 29 U.S.C. § 213(a)(1) ("[A]ny employee employed in a bona fide executive, administrative, or professional capacity ... or in the capacity of outside salesman."). See also ROTHSTEIN, supra note 39, at 651-59 (discussing the "white-collar exemptions" and various regulations enacted by the Department of Labor to determine when a "white-collar" employee is exempt from the FLSA's wage and hour requirements).

79. ROTHSTEIN, supra note 39 , at 634. 
intern minimum wages is if the intern is a trainee under the FLSA ${ }^{80}$ The Supreme Court established the trainee exception in Walling v. Portland Terminal Co., ${ }^{81}$ which held that trainees are not employees under the FLSA, and therefore not entitled to minimum wage and maximum hour protections. ${ }^{82}$ Unpaid interns have traditionally fallen under the trainee exception, however, the practice of hiring unpaid interns and simply assuming that they are trainees has recently come under attack. ${ }^{83}$ Increasing litigation has led to increasing uncertainty over what standard courts should apply to determine whether an unpaid intern is a trainee, and thereby exempt from the FLSA's minimum wage and maximum hour protections.

\section{Administrative Law under the FLSA}

In addition to the FLSA, Congress created the DOL as the regulatory agency tasked with enforcing labor and employment legislation. ${ }^{84}$ The Secretary of Labor is the head of the DOL and its purpose is to "foster, promote, and develop the welfare of the wage earners of the United States, to improve their working conditions, and to advance their opportunities for profitable employment." ${ }^{25}$ Congress has given the Secretary of Labor several enforcement actions by which to enforce the FLSA's minimum wage and maximum hour provisions, including the right to sue on behalf of affected employees, ${ }^{86}$ seek injunctive relief to prevent further violations, ${ }^{87}$ and impose civil penalties up to $\$ 1,100$ for repeated or willful violations. ${ }^{88}$ Within the DOL, Congress established the Wage and Hour Division. ${ }^{89}$ The Administrator of the Wage and Hour Division is under the direction of the Secretary of the DOL, and the Administrator's primary purpose is to monitor wage and hour issues

80. See, e.g., Glatt v. Fox Searchlight Pictures Inc., 293 F.R.D. 516, 530-31 (S.D.N.Y. 2013), reh'g granted in part, No. 11 Civ. 6784 WHP, 2013 WL 4834428 (S.D.N.Y. Aug. 26, 2013), mot. to certify appeal granted, No. 11 Civ. 6784 WHP, 2013 WL 5405696 (S.D.N.Y. Sept. 17, 2013) (applying the trainee exception analysis to the question of whether an unpaid intern was a trainee under Portland Terminal).

81. 330 U.S. 148, 153 (1947).

82. Id.

83. See Internship Litigation, supra note 9 , at 7.

84. 29 U.S.C. $\S 551$ (2012).

85. Id.

86. RothSTEIN, supra note 39 , at 674 (referring to 29 U.S.C. $§ 216(\mathrm{c})$ ).

87. Id. (referring to 29 U.S.C. $\S 217$ ).

88. Id. at 676 (referring to 29 U.S.C. § 216(e)(2)).

89. 29 U.S.C. $\S 204$ 
implicated by the FLSA. ${ }^{90}$

Similar to other administrative agencies, Congress has delegated rule-making authority to the DOL through the Administrative Procedures Act. ${ }^{91}$ The DOL publishes regulations that interpret the FLSA. ${ }^{92}$ These regulations generally "have the force of law" ${ }^{\prime \prime 3}$ and the DOL publishes the regulations in section 29 of the Code of Federal Regulations. ${ }^{94}$ Furthermore, the Supreme Court has held that these Federal Regulations are generally "given controlling weight unless they are arbitrary, capricious, or manifestly contrary to the statute." 95 In addition to these formal regulations, the DOL also publishes informal advisory or opinion letters stating how it would interpret and resolve issues arising under the FLSA. ${ }^{96}$ Unlike the formal regulations, these letters do not have the force of law and the Supreme Court generally does not give them high deference when interpreting the FLSA. ${ }^{97}$

\section{B. Interns under the FLSA}

The FLSA generally prohibits individuals from performing uncompensated work or services for the benefit of for-profit private sector businesses. ${ }^{98}$ The main exception to this rule is the trainee exception. Under the trainee exception, trainees are not employees under FLSA, therefore trainees are not entitled to the minimum wage and maximum hour protections under the FLSA. ${ }^{99}$ If a for-profit, private sector business wants to lawfully hire and employ an unpaid intern, the intern must qualify as a trainee under the trainee exception. The Supreme Court established the trainee exception in Walling v. Portland

90. See ROTHSTEIN, supra note 39, at 673.

91. 5 U.S.C. $\$ 553$ (2012).

92. See RothsteIN, supra note 39, at 673; see also 29 C.F.R. $\S \S 775.0-775.1$ (2014).

93. ROTHSTEIN, supra note 39 , at 673.

94. See 29 C.F.R. $\$ \S 500-899$ (2014).

95. Chevron, U.S.A., Inc. v. Natural Res. Def. Council, Inc., 467 U.S. 837, 844 (1984).

96. See, e.g., Fact Sheet \# 71: Internship Programs Under the Fair Labor Standards Act, U.S. DEP'T OF LABOR WAGE AND HOuR Division (April 2010) [hereinafter Fact Sheet], http://www.dol.gov/whd/regs/compliance/whdfs71.pdf.

97. Christensen v. Harris Cnty., 529 U.S. 576, 586 (2000).

98. See 29 U.S.C. $\S \S 203,206$ (2012) (outlining the mandatory minimum wage that employers must pay employees). However, the FLSA generally does not prohibit individuals from performing uncompensated work or services for the benefit of state or government agencies. See 29 U.S.C. $\S$ 203(4)(A).

99. See Walling v. Portland Terminal Co., 330 U.S. 148, 152 (1947) (holding that railroad trainees were not employees under the FLSA and explaining that the FLSA was not created to penalize businesses for providing instruction that mostly benefits the trainee). 
Terminal Co. ${ }^{100}$ Since Portland Terminal, Congress has not enacted any statutory provisions codifying the trainee exception within the FLSA. Additionally, the DOL has not enacted any formal regulations that interpret when a worker is a trainee or intern under the FLSA; however, the DOL has issued informal opinion letters that attempt to interpret how the trainee exception should apply to interns. ${ }^{101}$ The DOL's opinion letters have led to disagreement among the various Circuits over what standard to apply when determining whether an intern qualifies as a trainee. $^{102}$

\section{Portland Terminal Establishes the Trainee Exception}

In 1947, the Supreme Court created the trainee exception in Walling v. Portland Terminal Co. ${ }^{103}$ In Portland Terminal, the Court addressed the issue of whether unpaid individuals performing on-the-job training qualify as employees entitled to minimum wages under the FLSA. ${ }^{104}$ In Portland Terminal, uncompensated trainees brought suit against a railroad to seek compensation for their time spent training. ${ }^{105}$ The railroad was training the individuals to determine whether it would consider hiring them for brakemen employment positions. ${ }^{106}$ Before the railroad hired an applicant as a brakeman, the railroad required that an applicant complete seven or eight days of a preliminary training course. ${ }^{107}$ The training course instructed the trainees on how to do the work, and then had them do real work under supervision. ${ }^{108}$ If the trainee completed the course satisfactorily and demonstrated competence in the task, the railroad placed the trainee's name on a list the railroad would draw names from when it needed workers. ${ }^{109}$ The trainees did not

100. Id.

101. See, e.g., Fact Sheet, supra note 96.

102. See, e.g., Solis v. Laurelbrook Sanitarium \& Sch., Inc., 642 F.3d 518 (6th Cir. 2011) (employing a primary benefit test in finding that students working in school run nursing home were not employees); Reich v. Parker Fire Prot. Dist., 992 F.2d 1023, 1028 (10th Cir. 1993) (utilizing the six factor test in holding that firefighters in training were not employees); Donovan v. Am. Airlines, Inc., 686 F.2d 267, 271-72 (5th Cir. 1982) (discussing one court's three-criteria test and the Department of Labor's six factors to determine that flight attendant trainees were not employees).

103. Walling, 330 U.S. at 148.

104. Id.

105. Id. at 149 .

106. Id. at $149-50$.

107. Id. at 149 .

108. Id.

109. Id. at $149-50$. 
receive any pay or compensation for their time in the training program. ${ }^{110}$ The trainees brought suit against the railroad alleging that they were entitled to minimum wage compensation under the FLSA. ${ }^{111}$

In its opinion, the Court tried to determine whether the trainees were employees under the FLSA as a result of being "employ[ed]" by the railroad. ${ }^{112}$ The Court found that the trainees did not displace any of the railroad's regular employees and did not expedite the railroad's work, but rather, the trainees actually impeded the railroad's work in some circumstances. ${ }^{113}$ Furthermore, the Court said the FLSA's definition of employ ("to suffer or permit to work") did not qualify all persons who perform work as employees under the FLSA. ${ }^{114}$ If that were the case, then "all students would be employees of the school or college they attended, and as such entitled to receive minimum wages." "115 The Court reasoned that these trainees were like students who were receiving free training for their own benefit. ${ }^{116}$ Additionally, the railroad received no "immediate advantage" from the work performed by the trainees. ${ }^{117}$ Thus, the Court distinguished a trainee from an employee, and established the trainee exception to the FLSA's definition of employee. $^{118}$

\section{DOL's Opinion Letters on Interns}

Using Portland Terminal's rationale for exempt trainees, ${ }^{119}$ the Wage and Hour Division of the DOL issued an opinion letter in 2010 applying the trainee exception to interns. ${ }^{120}$ The opinion letter, Fact Sheet \#71, set out a six-factor test for determining "whether interns must be paid the minimum wage and overtime under the FLSA for the services that they provide to 'for-profit' private sector employees." 121 The letter stated that

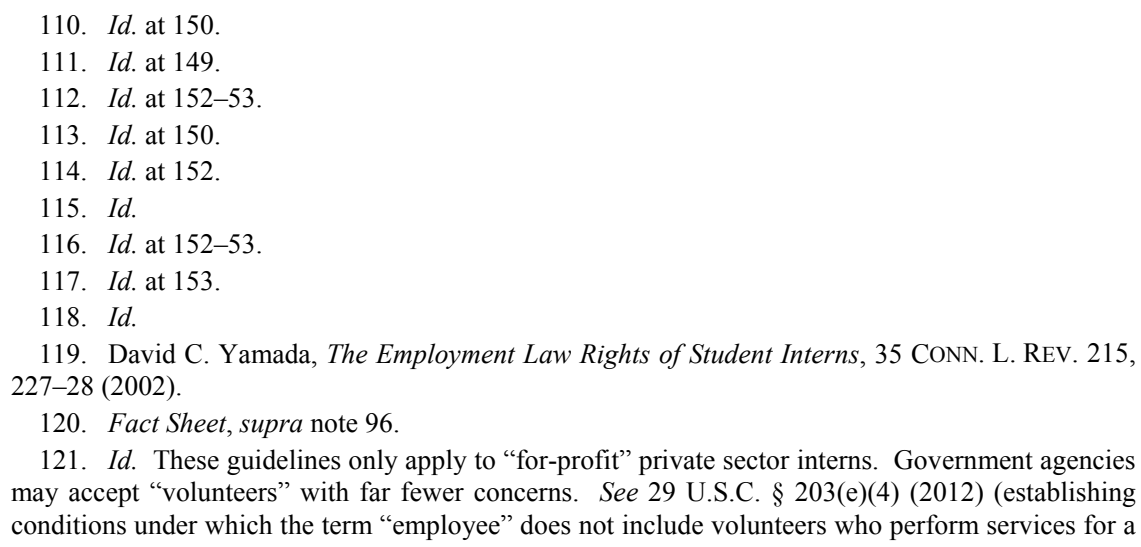

121. Id. These guidelines only apply to "for-profit" private sector interns. Government agencies may accept "volunteers" with far fewer concerns. See 29 U.S.C. § 203(e)(4) (2012) (establishing conditions under which the term "employee" does not include volunteers who perform services for a 
if all six factors of the test are met, then there is no employment relationship and the FLSA's minimum wage and maximum hour provisions would not apply to the intern. ${ }^{122}$ The letter also stated that the determination depends on "all of the facts and circumstances of each such [internship] program." "123 The six factors of the test are:

1. The internship, even though it includes actual operation of the facilities of the employer, is similar to training which would be given in an educational environment;

2. The internship experience is for the benefit of the intern;

3. The intern does not displace regular employees, but works under close supervision of existing staff;

4. The employer that provides the training derives no immediate advantage from the activities of the intern; and on occasion its operations may actually be impeded;

5. The intern is not necessarily entitled to a job at the conclusion of the internship; and

6. The employer and the intern understand that the intern is not entitled to wages for the time spent in the internship. ${ }^{124}$

In September 2013, the DOL issued another opinion letter, this time to the American Bar Association, addressing the issue of law students working as unpaid interns at for-profit private law firms. ${ }^{125}$ The letter applied the same six-factor test as Fact Sheet \#71; however, it tweaked some of the prongs, elaborated on all of them, and added an additional pro bono requirement. ${ }^{126}$ Regarding the "no immediate advantage" prong, the DOL said law students may work as unpaid interns at forprofit law firms, as long as they work exclusively on non-fee-generating, pro bono activities. ${ }^{127}$ For the pro bono work requirement, the letter said interns' work activities may not "involve potential fee-generating activities . . . billable work or free up staff resources for billable work

public agency).

122. Fact Sheet, supra note 96.

123. Id.

124. Id.

125. See Letter from M. Patricia Smith, Solicitor of Labor, U.S. Dep't of Labor, to Laurel G. Bellows, Immediate Past President, ABA (Sep. 12, 2013), http://www.americanbar.org/content/ dam/aba/images/news/PDF/MPS_Letter_reFLSA_091213.pdf [hereinafter ABA Intern Letter].

126. Id.

127. See id. 
that would otherwise be utilized for pro bono work ...."128 The letter also said firms cannot derive an immediate advantage from interns' activities; however, they can derive "long-term benefits such as general reputational benefits associated with pro bono activities." 29 The letter concluded by saying its analysis does not apply to law school graduates. $^{130}$

While the DOL has the power to enforce the FLSA's provisions, ${ }^{131}$ its opinion letters serve only as persuasive authority. ${ }^{132}$ The letters do not have the weight of statutory law or administrative regulations. ${ }^{133}$ Courts may consider the DOL's letters in intern-employee matters; however, they are not required to adhere to the letters' recommendations when deciding a case. ${ }^{134}$ Some courts have applied the advisory letters' six-factor test when determining whether unpaid interns qualify under the trainee exception, ${ }^{135}$ while other courts have dismissed the DOL's opinion letters altogether. ${ }^{136}$

\section{Courts Split on What Standard to Apply to Interns}

Courts are undecided on what standard to apply for determining whether an intern may be exempt from the FLSA. The Sixth Circuit has disregarded the DOL's six-prong test and instead applies a primary beneficiary test. ${ }^{137}$ The Fifth Circuit has adopted the six-prong test and seemingly applies the six prongs as all or nothing elements. ${ }^{138}$ The Tenth Circuit has also adopted the six-prong test; however, rather than applying the six prongs as elements, it applies the six prongs as factors, which it considers within the "totality of the circumstances."139 The Second Circuit has not decided the issue; however, it recently heard the issue on

\footnotetext{
128. $I d$.

129. Id.

130. Id

131. Yamada, supra note 119, at 227.

132. Id. at 229-30.

133. See id. (providing that "these opinion letters do not carry the same weight as court decisions, or even final administrative determinations").

134. Id.

135. See, e.g., Glatt v. Fox Searchlight Pictures Inc., 293 F.R.D. 516 (S.D.N.Y. 2013), reh'g granted in part, No. 11 Civ. 6784 WHP, 2013 WL 4834428 (S.D.N.Y. Aug. 26, 2013), mot. to certify appeal granted, No. 11 Civ. 6784 WHP, 2013 WL 5405696 (S.D.N.Y. Sept. 17, 2013).

136. See, e.g., Solis v. Laurelbrook Sanitarium \& Sch., Inc., 642 F.3d 518 (6th Cir. 2011).

137. Id.

138. Donovan v. Am. Airlines, Inc., 686 F.2d 267 (5th Cir. 1982).

139. Reich v. Parker Fire Prot. Dist., 992 F.2d 1023 (10th Cir. 1993).
} 
appeal and the parties are awaiting the decision. ${ }^{140}$ The appeal came from two separate cases in the United States District Court for the Southern District of New York, in which the lower courts adopted the six-prong "totality of the circumstances" standard. ${ }^{141}$ The fact that several courts have adopted different standards illustrates the significant amount of legal uncertainty that currently surrounds unpaid internships.

\section{a. The Primary Beneficiary Test}

In Solis v. Laurelbrook Sanitarium and School, Inc., ${ }^{142}$ the Sixth Circuit adopted a primary beneficiary test to determine whether an intern or trainee is an employee under the FLSA. Solis involved students at Laurelbrook boarding school in Tennessee. ${ }^{143}$ Laurelbrook structured their educational program to educate students in a traditional academic setting as well as in a practical, hands-on setting. ${ }^{144}$ As part of the practical learning, students worked in a nursing home operated by Laurelbrook. ${ }^{145}$ The students spent half their time on classroom learning and half their time on practical nursing skills. ${ }^{146}$ Staff members supervised the students while they participated in the practical training. ${ }^{147}$ Neither the school nor the nursing home paid the students, nor were the students entitled to a job at the nursing home after graduation. ${ }^{148}$

After learning of the program, the Secretary of the DOL brought a claim against Laurelbrook for violating the child labor provision of the FLSA. ${ }^{149}$ The secretary sought injunctive relief against future violations by the school. ${ }^{150}$ The district court denied the Secretary's request for relief on the basis that the students were not employees under the FLSA,

140. Glatt v. Fox Searchlight Pictures, Inc.: Chamber Urges Second Circuit to Adopt Primary Benefits Test as Standard to Determine Whether Interns are Employees under the Fair Labor Standards Act and New York Labor Law, U.S. ChAmBER LiTIG. CTR., http://www.chamber litigation.com/glatt-v-fox-searchlight-pictures-inc (last visited Nov. 24, 2014).

141. Xuedan Wang v. Hearst Corp., 293 F.R.D. 489 (S.D.N.Y. 2013), mot. to certify appeal granted, No. 12 CV 793 HB, 2013 WL 3326650 (S.D.N.Y. June 27, 2013); Glatt v. Fox Searchlight Pictures Inc., 293 F.R.D. 516, 516 (S.D.N.Y. 2013), reh'g granted in part, No. 11 Civ. 6784 WHP, 2013 WL 4834428 (S.D.N.Y. Aug. 26, 2013), mot. to certify appeal granted, No. 11 Civ. 6784 WHP, 2013 WL 5405696 (S.D.N.Y. Sept. 17, 2013). Both cases are currently pending appeal.

142. 642 F.3d 518, 518 (6th Cir. 2011).

143. Id. at 519 .

144. Id. at 520 .

145. Id.

146. Id.

147. Id. at 521 .

148. Id.

149. Id.

150. Id. 
and therefore not subject to the FLSA's child labor provisions. ${ }^{151}$

The issue on appeal was whether the student workers were employees under the FLSA. ${ }^{152}$ First, the court said that simply labeling the student workers as "students at a vocational school" was not, on its own, sufficient to find that the students were exempt trainees rather than employees under the FLSA. ${ }^{153}$ Next, the court considered what test it should apply to determine whether the students were trainees or employees. ${ }^{154}$

The first test the court considered was the DOL's six-prong test. ${ }^{155}$ The court interpreted the six-prong test as a standard that could only be satisfied if all six prongs of the test were met. ${ }^{156}$ The court found the test's all or nothing application to be a poor method for determining employee status in an intern-training situation. ${ }^{157}$ The court believed it was too rigid and failed to consider the totality of the circumstances of the situation, therefore the court rejected the six-prong test and adopted the so-called primary beneficiary test. ${ }^{158}$

The primary beneficiary test determines a student's (or intern's) status under the FLSA by looking at the educational or training situation involved and determining if the student was the primary beneficiary of the work performed. ${ }^{159}$ If the student received the primary benefit of the work through the educational value received, the student is considered a trainee and is therefore exempt from the FLSA. ${ }^{160}$ However, if the employer received the primary benefit of the relationship, the student is considered an employee who is entitled to wages under the FLSA. ${ }^{161}$ The Solis court believed the primary benefit test was more consistent with Portland Terminal's trainee exception than the DOL's six-prong test. $^{162}$ Additionally, the court believed the primary benefit test was the best way to distinguish between interns and employees under the

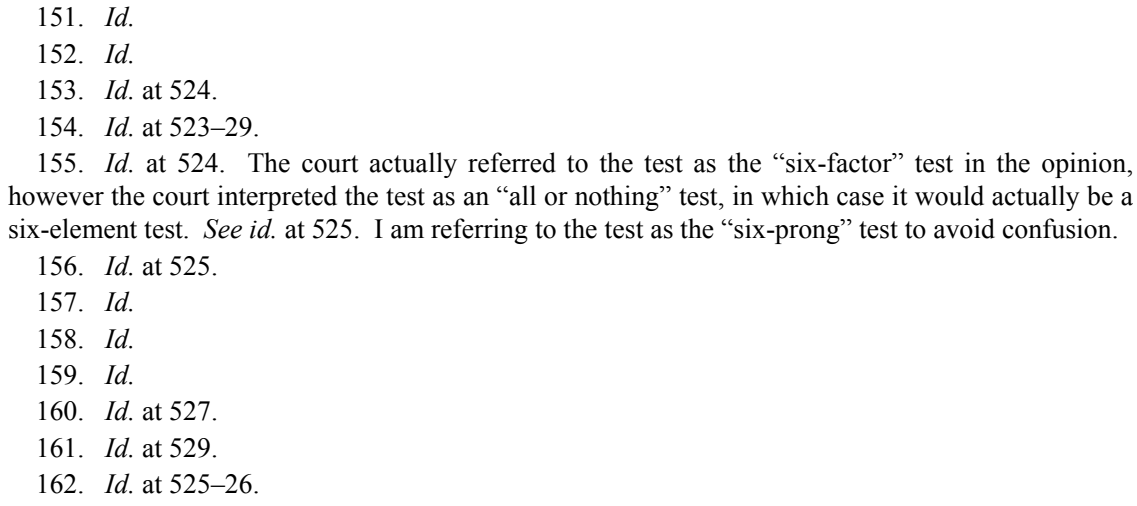


FLSA. $^{163}$

Applying the primary benefit test to the facts in the case, the court found that both parties received benefits from the work performed, however, some of the benefits were offset by the students not displacing paid workers and instructors spending extra time supervising the students instead of being able to perform their own work. ${ }^{164}$ Furthermore, the court found that the students received significant tangible benefits such as hands-on training, and significant intangible benefits such as a wellrounded education and life lessons on the value of hard work. ${ }^{165}$ Weighing the benefits received by both parties, the court found that the students received the primary benefit of the school's training program, and therefore were not employees under the FLSA. ${ }^{166}$

\section{b. The Six-Prong Test}

Courts are split on how to actually apply the DOL's six-prong test to interns and trainees. Some courts have applied the six-prongs as six elements in an "all or nothing" approach, where all of the points must be met to consider the intern a trainee. ${ }^{167}$ Other courts have applied the six points as six factors that should be considered within the "totality of the circumstances." 168 Under the totality of the circumstances approach, the court may give any factor more or less weight than the other factors, and all six factors do not have to be met for the intern to be considered a trainee.

Some of the confusion over how to apply the six points can likely be attributed to the contradictory language contained in the DOL's Fact Sheet \#71. Fact Sheet \#71 says "[i]f all of the factors listed above are met, an employment relationship does not exist," but also says "[t]he determination of whether an internship or training program meets this exclusion depends upon all of the facts and circumstances of each such program." 169 The first line's language ("all of the factors must be met")

\footnotetext{
163. Id. at 529 .

164. Id. at $530-31$.

165. Id. at 531 .

166. Id.

167. See Donovan v. Am. Airlines, Inc. 686 F.2d 267, 273 (5th Cir. 1982).

168. See, e.g., Reich v. Parker Fire Prot. Dist., 992 F.2d 1023 (10th Cir. 1993).

169. Fact Sheet, supra note 96; see also Xuedan Wang v. Hearst Corp., 293 F.R.D. 489 (S.D.N.Y. 2013), mot. to certify appeal granted, 12 CV 793 HB, 2013 WL 3326650 (S.D.N.Y. June 27, 2013) ("While the weight to be given to these factors is far from crystal clear, the Fact Sheet adds to the confusion with the introductory language: "whether an internship or training program meets this exclusion depends upon all of the facts and circumstances of each such program.'”).
} 
suggests an all or nothing application, while the second line's language ("depends on all the facts and circumstances") suggests weighing the six points within the totality of the circumstances. ${ }^{170}$

i. All or Nothing Application of the Six-Prong Test

An all or nothing application of the six-prong test creates a difficult standard for employers trying to hire unpaid interns because they would have to satisfy all six points. The language of the DOL's Fact Sheet \#71, stating "[i]f all of the factors listed above are met, an employment relationship does not exist under the FLSA," seems to imply a sixelement, all or nothing application. ${ }^{171}$

In Donovan v. American Airlines, Inc., ${ }^{172}$ the Fifth Circuit appeared to interpret the DOL's six-prong test as an all or nothing test. The issue in Donovan was whether job applicants for American Airlines were employees under FLSA during their preliminary job training. ${ }^{173}$ Several thousand applicants applied for the flight attendant positions and of those thousands of applicants, American Airlines only selected approximately 800 for training. ${ }^{174}$ Once American Airlines selected the applicants, the company told the applicants they would have to go to Dallas to attend the required flight attendant training. ${ }^{175}$ If the selected applicants completed the training, American Airlines still did not guarantee them a job, although the assumption was that they would receive a job offer. ${ }^{176}$ American Airlines did not pay the applicants but it did provide their meals and housing for the duration of the program. ${ }^{177}$ The training lasted forty hours a week over the course of four to five weeks. ${ }^{178}$ The training took place in classrooms and mock-up aircraft facilities, and the applicants did not supplement the work of, or take the place of, any American Airlines employees. ${ }^{179}$ The Secretary of Labor brought action against American Airlines, claiming that the training applicants were employees under the FLSA and therefore entitled to minimum wages. ${ }^{180}$

170. Fact Sheet, supra note 96.

171. Id.

172. 686 F.2d 267 (5th Cir. 1982).

173. $I d$.

174. Id. at 268 .

175. Id.

176. Id. at $268-69$.

177. Id. at 269 .

178. Id.

179. Id.

180. Id. at 268 . 
The Donovan court applied Portland Terminal's trainee standard to determine whether the applicants were trainees or employees. ${ }^{181}$ Applying Portland Terminal, the Donovan court concluded that the applicants were trainees, and therefore not entitled to minimum wages. ${ }^{182}$ The court supported its conclusion with the DOL's six-prong test. ${ }^{183}$ The court applied the six-prong test to the American Airline training program, stating:

The trainees here are not employees by each of those criteria: the training is similar to that given at vocational schools; the training is for the benefit of the trainees; the trainees do not displace regular employees and work under close observation; the employer derives no immediate benefit from the training; the trainees are not necessarily entitled to a job at the conclusion of the training, and the employer and the trainee understand that no wages will be paid for the training.

According to the six-prong test, the trainees were not employees. ${ }^{185}$ Donovan did not expressly state that the test was an all or nothing test; however, that could be reasonably inferred by the court pointing out that "each of those criteria" was satisfied. ${ }^{186}$

\section{ii. Totality of the Circumstances Application of the Six-Prong Test}

The more common application of the six-prong test is one that considers the totality of the circumstances. The totality of the circumstances application views all six prongs of the test as separate, individual factors to be considered with the totality of the circumstances when determining whether an intern is exempt from the FLSA. The Tenth Circuit ${ }^{187}$ and the District Court for the Southern District of New York ${ }^{188}$ have both adopted the totality of the circumstances application.

181. Id. at $271-72$.

182. Id. at $272-73$.

183. Id. at 273 .

184. Id. Donovan was decided in 1982 and applied an older version of the DOL's six-prong test; nevertheless, the test was substantially the same as the current six-prong test in the DOL's Fact Sheet \#71. Compare id. at 273 n.7, with Fact Sheet, supra note 96.

185. Donovan, 686 F.2d at 273.

186. Id.

187. Reich v. Parker Fire Prot. Dist., 992 F.2d 1023 (10th Cir. 1993).

188. Xuedan Wang v. Hearst Corp., 293 F.R.D. 489 (S.D.N.Y. 2013), mot. to certify appeal granted, 12 CV 793 HB, 2013 WL 3326650 (S.D.N.Y. June 27, 2013); Glatt v. Fox Searchlight Pictures Inc., 293 F.R.D. 516 (S.D.N.Y. 2013), reh'g granted in part, 11 CIV. 6784 WHP, 2013 WL 4834428 (S.D.N.Y. Aug. 26, 2013), mot. to certify appeal granted, 11 CIV. 6784 WHP, 2013 WL 5405696 (S.D.N.Y. Sept. 17, 2013). 
The Tenth Circuit applied the totality of the circumstances six-prong test in Reich v. Parker Fire Protection District. ${ }^{189}$ In Reich, the Secretary of Labor brought suit against a firefighting training academy, Parker Fire Protection District (Parker). ${ }^{190}$ The Secretary brought the suit on behalf of four firefighters who trained at the academy, but were not paid for their time at the training academy. ${ }^{191}$ The Secretary claimed that the trainees were actually employees entitled to minimum wages under the FLSA. ${ }^{192}$ Both the Secretary and Parker agreed that the DOL's sixprong test was the proper standard to apply; however, they disagreed over how the test should be applied. ${ }^{193}$ The Secretary argued that the test should be applied as a strict "all or nothing standard," while Parker argued that the test should be applied as a "totality of the circumstances test" and that the court's determination "should not turn on the presence or absence of one factor in the equation."

The court began its analysis by saying it was not required to give a high level of deference to either the DOL's six-prong test or the Secretary's interpretation of how the test should be applied. ${ }^{195}$ The court acknowledged that Portland Terminal supported the six-prong test, however it did not believe Portland Terminal supported a strict all or nothing application of the six-prong test. ${ }^{196}$ Furthermore, the court believed that the DOL's language in its interpretation of the six-prong test supported a totality of the circumstances approach. ${ }^{197}$ The court said the six prongs were relevant for consideration but were not absolute, determinative elements for deciding whether a trainee is an employee under the FLSA. ${ }^{198}$ Therefore, the Tenth Circuit held that the six-prong test should be applied as a totality of the circumstances test rather than an all or nothing test. ${ }^{199}$

In 2013, two cases in the Southern District of New York also applied the totality of the circumstances six-prong test-Xuedan Wang v. Hearst

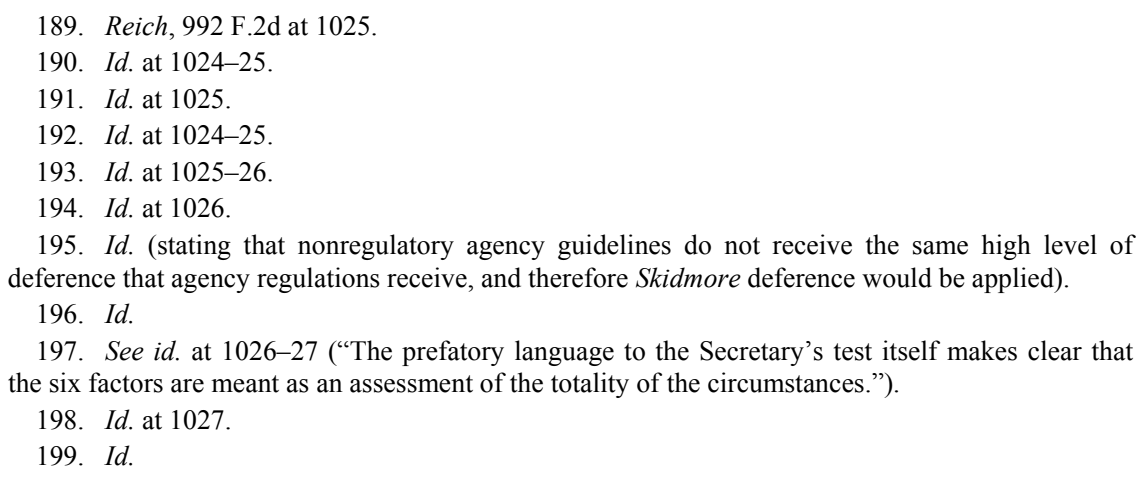


Corporation $^{200}$ and Glatt v. Fox Searchlight Pictures, Inc. ${ }^{201}$ These cases are significant because they are the first high-profile cases in which unpaid interns, rather than job applicants or trainees, sued employers over unpaid wages.

In Wang, the issue was whether a group of unpaid interns had been illegally misclassified as interns (rather than employees under the FLSA) and wrongly denied compensation. ${ }^{202}$ Xuedan Wang was the lead plaintiff for a class of plaintiffs who worked as unpaid interns for Hearst Corporation (Hearst) in New York, one of the largest magazine publishers in the world. ${ }^{203}$ The plaintiffs' duties at Hearst included a wide variety of activities including: researching articles online, responding to emails, organizing files, running errands, and other office activities. ${ }^{204}$ The plaintiffs moved for partial summary judgment on the issue of whether they were employees under the FLSA. ${ }^{205}$

In its decision, the court acknowledged that the term intern is not defined or listed as an exception to the term employee anywhere in the FLSA. $^{206}$ Therefore, the court said that Portland Terminal's trainee exception was the controlling standard for whether an intern is an employee under the FLSA. ${ }^{207}$ For guidance on the Portland Terminal standard, the court looked to the DOL's Fact Sheet \#71, which "put[] some meat on the [Portland Terminal] bones." ${ }^{208}$ The court adopted the six-prong test; however, it was unsure how much weight to give to each part of the test and was confused by the language used by the DOL in Fact Sheet \#71. ${ }^{209}$ One part of the Fact Sheet said that the determination "depend[ed] upon all of the facts and circumstances of each such program" while another part said that an employment relationship did not exist "[i]f all of the factors listed above [were] met...." ${ }^{210}$ The

200. Xuedan Wang v. Hearst Corp., 293 F.R.D. 489 (S.D.N.Y. 2013), mot. to certify appeal granted, 12 CV 793 HB, 2013 WL 3326650 (S.D.N.Y. June 27, 2013).

201. Glatt v. Fox Searchlight Pictures Inc., 293 F.R.D. 516 (S.D.N.Y. 2013), reh'g granted in part, 11 CIV. 6784 WHP, 2013 WL 4834428 (S.D.N.Y. Aug. 26, 2013), mot. to certify appeal granted, 11 CIV. 6784 WHP, 2013 WL 5405696 (S.D.N.Y. Sept. 17, 2013).

202. Xuedan Wang, 293 F.R.D. at 490.

203. Id. at 490-92. Another issue in the case was whether the plaintiffs satisfied the requirements for class certification, with the court finding that they failed to satisfy the requirements for class certification. Id. at 494-98.

204. Id. at 491-92.

205. Id. at 492 .

206. Id.

207. Id. at 492 .

208. Id. at 493 .

209. Id.

210. Fact Sheet, supra note 96. 
plaintiffs argued for an "immediate advantage" standard, claiming that when an employer gains an immediate or direct advantage from his or her interns, the interns have been "suffered or permitted [to] work" under the FLSA and must be compensated for the work. ${ }^{211}$ Alternatively, if the court did not apply the proposed immediate advantage standard, the plaintiffs argued for an all or nothing standard of application for the sixprong test. $^{212}$ The defendant argued that the standard should be a "balancing of the benefits test" which looked at the "totality of the circumstances to evaluate the "economic reality' of the relationship.","13

The Wang court agreed with the defendants and found the totality of the circumstances to be the correct standard. ${ }^{214}$ The court chose the totality of the circumstances approach because it was similar to the Supreme Court's reasoning in Portland Terminal. ${ }^{215}$ The court said that Portland Terminal did not establish a one-dimensional test, but rather a totality of the circumstances test. ${ }^{216}$ Therefore, the court rejected the plaintiffs' argument that the standard should be either a one-dimensional "immediate advantage" standard or an "all or nothing" standard of application of the DOL's six-prong test. ${ }^{217}$

Furthermore, the Wang court's opinion implied that the totality of the circumstances standard considers circumstances outside of the DOL's six-prong test. ${ }^{218}$ However, the court did not altogether dismiss the sixprong test because it thought the six-prong test provided a framework for a totality of the circumstances analysis. ${ }^{219}$ Therefore, the court essentially adopted a totality of the circumstances application of the DOL's six-prong test and denied the plaintiffs' motion for summary judgment because a "genuine dispute and material issues of fact exist[ed], at least with respect to the first, second, third, and fourth factors." 220

Approximately one month after the Wang decision, Glatt v. Fox Searchlight Pictures brought another claim of illegal unpaid internships

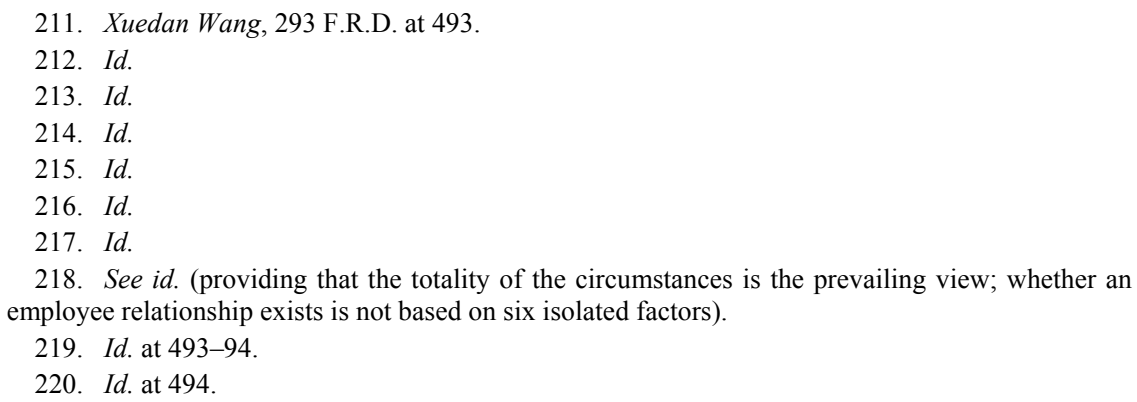


before the Southern District of New York. ${ }^{221}$ Two of the plaintiffs in Glatt were unpaid interns who worked on the production set for the film Black Swan. ${ }^{222}$ The primary defendant in the case was Fox Entertainment Group, Inc. (Fox). ${ }^{223}$

The plaintiff's claim focused on Fox's unpaid internships. ${ }^{224}$ Fox hired the plaintiffs as unpaid interns. ${ }^{225}$ The plaintiffs claimed they were victims of an internship program that used interns to perform work that would have required Fox to hire paid employees if not for the work done by the interns. ${ }^{226}$ The plaintiffs claimed that Fox violated the FLSA by misclassifying them as unpaid interns, when in reality they were employees entitled to wages. ${ }^{227}$ Both parties moved for summary judgment and the court granted the plaintiffs' summary judgment motion, finding that the plaintiffs were misclassified as interns and should have been classified as employees and paid wages in accordance with the FLSA. ${ }^{228}$

In the opinion, the court had to determine whether the plaintiffs were employees under the FLSA. ${ }^{229}$ Since the FLSA's definition of employee is "any individual employed by an employer," the court said the plaintiffs would be deemed employees unless they fit into the narrow trainee exception established in Portland Terminal. ${ }^{230}$ The Second Circuit had never decided an unpaid intern case, so the court had no guiding precedent and had to decide which test to apply to determine whether the interns fit into the narrow trainee exception. ${ }^{231}$ First, the court considered the Sixth Circuit's primary beneficiary test. ${ }^{232}$ It found the test to be too "subjective and unpredictable."233 The court also believed the test was not supported by Portland Terminal. ${ }^{234}$

Next, the court considered and ultimately adopted the DOL's six-

221. Glatt v. Fox Searchlight Pictures Inc., 293 F.R.D. 516 (S.D.N.Y. 2013), reh'g granted in part, 11 CIV. 6784 WHP, 2013 WL 4834428 (S.D.N.Y. Aug. 26, 2013), mot. to certify appeal granted, 11 CIV. 6784 WHP, 2013 WL 5405696 (S.D.N.Y. Sept. 17, 2013).

222. Id. at 522 .

223. Id.

224. Id.

225. Id.

226. Id. at 533 .

227. Id. at 522 .

228. Id. at 534 .

229. Id. at 531 .

230. Id. at 532 .

231. Id. at 531 .

232. Id. at 532 .

233. $I d$.

234. Id. at 531 . 
prong test. ${ }^{235}$ The court found the six-prong test to be supported by Portland Terminal because Portland Terminal established a "narrow exception to an expansive definition." 236 The six-prong test created a much narrower trainee exception than the primary beneficiary test and considered some of the same factors the Supreme Court considered in Portland Terminal. ${ }^{237}$ The Glatt court also adopted the six-prong test because the test was created by the agency responsible for enforcing the FLSA, thus entitling it to deference over other tests. ${ }^{238}$

In applying the test, the court deviated slightly from the language in the DOL's letter. The letter seemingly required that all six prongs be met to qualify for the exception. ${ }^{239}$ The court disagreed with this application, and instead adopted the totality of the circumstances approach, under which no single factor was controlling. ${ }^{240}$ Applying the six prongs of the test to the totality of the circumstances of the case, the court found the plaintiffs did "not fall within the narrow 'trainee' exception to the FLSA's broad coverage." ${ }^{241}$ The plaintiffs were not receiving any educational value from the internship because they were performing basic tasks that did not require any skills, such as operating the copy machine and making coffee. ${ }^{242}$ While the plaintiffs did benefit somewhat from the intern program, the employer (Fox) received the primary benefit from the program by obtaining free labor from the plaintiffs. ${ }^{243}$ By performing free labor for Fox, Fox did not have to hire paid employees to perform the work or pay existing employees for extra time worked; therefore, the plaintiffs were displacing regular employees. ${ }^{244}$ While the plaintiffs understood they were not entitled to wages, the court gave very little weight to this factor because the plaintiffs could not waive their right to wages under the FLSA and Fox had the superior bargaining power in the relationship. ${ }^{245}$ Therefore, based on the totality of the circumstances, the court held that the plaintiffs did not fall into the "narrow 'trainee' exception to the FLSA's broad coverage" and were

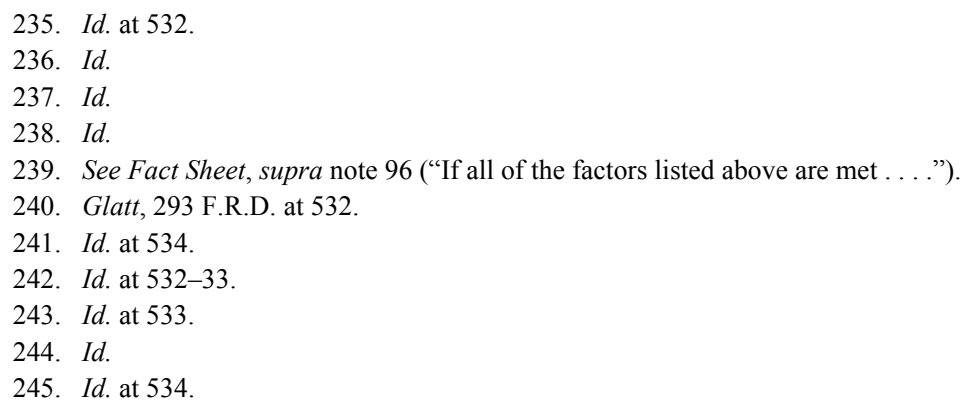


employees entitled to wages. ${ }^{246}$

III. ANALYSIS

As the litigation over unpaid internships has increased, so has the level of uncertainty regarding what standard courts should apply to determine the legal status of interns. Courts cannot settle on a clear, consistent standard, which has led to the uncertainty. The legal uncertainty over internships is problematic for employers, interns, and the overall job market. To resolve this lingering uncertainty, the DOL should enact a regulatory provision that establishes a standard for determining whether an intern is exempt from the FLSA's minimum wage and maximum hour provisions. The standard imposed by the regulation should be a modified version of the all or nothing six-prong test.

\section{A. The DOL Should Enact a Formal Regulation that Creates a Modified All or Nothing Six-Prong Test for Determining Whether an Intern is Exempt from the FLSA}

The DOL should enact a regulatory provision that uses a modified version of the DOL Fact Sheet's six-prong test, applied in the all or nothing manner, so that each part is applied, and all prongs must be met for an intern to be exempt from the FLSA. A regulation enacting a modified version of the all or nothing six-prong test would establish a reliable standard by clarifying the second and fourth element of the test. $^{247}$ This improved six-prong test would adhere to the trainee exception in Portland Terminal and give more legal weight to the standard by being enacted as a formal regulation rather than an advisory or opinion letter.

\section{A Modified Version of the All or Nothing Six-Prong Test Would} Establish a Reliable Standard

To enact a reliable, clear standard, the six-prong test should be enacted as an all or nothing six-prong test with changes made to the second and fourth element to improve the test's objectivity and clarity. The all or nothing six-prong test is superior to both the primary beneficiary test and the totality of the circumstances six-prong test

246. Id.

247. See infra Part III.A.1. 
because it is more objective and predictable than the other two tests. It is more objective and predictable because six, clearly defined prongs must all be met for an intern to be exempt from the FLSA. To improve the all or nothing six-prong test, the second element should be amended to "the internship experience benefits the interns." 248 The fourth element should be amended to "the employer derives no immediate advantage from the intern's activities, meaning that the intern's activities do not: i) generate revenue or billable hours for the employer, ii) free up the employer or paid employees to work on more profitable activities, or iii) allow the employer to pursue any activities that the employer derives an advantage from, when the employer would not have pursued that activity, but for the activities of the intern." ${ }^{249}$ In its entirety, this modified all or nothing six-prong test would read:

In the case of for-profit private sector internships or training programs, all six of the following elements must be satisfied in order to show that an employment relationship does not exist under the FLSA:

1) the internship, even though it includes actual operation of the facilities of the employer, is similar to training which would be given in an educational environment;

2) the internship experience benefits the intern;

3) the intern does not displace regular employees, but works under close supervision of existing staff;

4) the employer derives no immediate advantage from the intern's activities, meaning that the intern's activities do not: i) generate revenue or billable hours for the employer, ii) free up the employer or paid employees to work on revenue generating or more profitable activities, or iii) allow the employer to pursue any activities that the employer derives an advantage from, when the employer would not have pursued that activity, but for the activities of the intern;

5) the intern is not necessarily entitled to a job at the conclusion of the internship; and

6) the employer and the intern understand that the intern is not entitled to wages for the time spent in the internship.

\footnotetext{
248. The second criteria currently states, "The internship experience is for the benefit of the intern." See Fact Sheet, supra note 96.

249. The fourth criteria currently states, "The employer that provides the training derives no immediate advantage from the activities of the intern; and on occasion its operations may actually be impeded." Id.
} 
If one of these six elements are not satisfied, then an employment relationship exists and the intern or trainee is an "employee" under the FLSA.

This improved six-prong test would create a reliable standard by being applied as an all or nothing six-prong test rather than a primary beneficiary test or a totality of the circumstances six-factor test. Of the three tests applied by the different circuits, the all or nothing six-prong test is the most predictable and most objective.

First, the all or nothing six-prong test is more predictable and reliable than the primary beneficiary test because the primary beneficiary test is highly subjective and unpredictable. The court in Glatt recognized the problem of subjectivity when it rejected the primary beneficiary test. ${ }^{250}$ Under the primary beneficiary test, if the intern receives the primary benefit of the relationship, then no employment relationship exists and the intern is not entitled to minimum wages or other protections under the FLSA. ${ }^{251}$ This test is highly subjective and impossible to predict. The primary benefit a party receives from an employment relationship is based entirely on that party's own, subjective perspective.

For example, assume a college student, Jake, is hired as an unpaid intern at a large record label. Jake works about 30 hours a week, is not receiving college credit, and his only duties are performing unskilled, remedial tasks such as making coffee or organizing files. However, every Thursday Jake receives the subjective benefit of getting to meet and talk to his favorite musician, Mick Jagger, for five to ten minutes when Mick comes into the office for his weekly meeting. Applying the primary beneficiary test to this scenario, Jake's employer, the record label, may only receive about $\$ 218$ worth of free labor each week; ${ }^{252}$ however, Jake's subjective benefit of getting to meet his favorite musician each week may surpass the record label's \$218 weekly benefit. Therefore, under the primary beneficiary test, a court could find that Jake was the primary beneficiary and that he is not entitled to minimum wages or any other protections under the FLSA. Jake would not be considered an employee despite the fact that he was performing activities the record label would otherwise have to pay an employee to perform, was not receiving any educational value, was not receiving any college credits, all while providing a material, monetary benefit to the record company

250. Glatt, 293 F.R.D. at 532.

251. Solis v. Laurelbrook Sanitarium \& Sch., Inc., 642 F.3d 518, 529 (6th Cir. 2011).

252. The approximate figure of $\$ 218$ was calculated by multiplying the current federal minimum wage of $\$ 7.25$ an hour, by 30 hours, which equals $\$ 217.50$. 
and only receiving immaterial benefits in return. This illustrates the subjective nature of the test and how it could be construed in favor of unpaid labor. Additionally, the test is unpredictable and unreliable for an employer trying to implement an unpaid internship program that complies with the law because an employer will not know beforehand what a court may determine are benefits to each party and what weight a court will give to those benefits. A hundred different courts could apply the primary beneficiary test to the same set of facts, and be split as to who the primary beneficiary is in the relationship.

The all or nothing six-prong test is also more predictable and reliable than the six-factor "totality of the circumstances" test. The method of application of the same six criteria is significant because the two applications create two completely different tests that could reach two different outcomes when applied to the same fact pattern. ${ }^{253}$ The totality of the circumstances test is flawed because it creates the same subjective, unpredictable test as the primary beneficiary test. Courts are free to give more or less weight to any of the six separate factors, or even to completely disregard any of the factors they do consider important. ${ }^{254}$ The second factor-whether the internship was for the benefit of the intern - can also undermine the six-factor test by converting it into the primary beneficiary test, if the court gives the second factor predominant weight over the other factors. Glatt illustrated this potential problem when it identified the defendants as the "primary beneficiaries of the relationship." 255 Like the primary beneficiary test, the totality of the circumstances application of the six-prong test does not provide the parties in a work relationship with a reliable, predictable standard for when an intern may be considered an employee under the FLSA.

The only problem with the all or nothing six-prong test is that two of its elements are subjective and unclear. The second element currently requires that " $[t]$ he internship experience is for the benefit of the intern." 256 Unlike the totality of the circumstances application, the all or nothing application of this test removes the possibility that this element could turn the entire test into a primary beneficiary test. However, the second element is still a subjective element that depends on the subjective balancing of who benefits the most from the relationship. It

253. See Yamada, supra note 119, at 230-31 (noting the difference between the Fifth and Tenth Circuits).

254. See Glatt, 293 F.R.D. 516, 534 (stating that the employers satisfied the sixth factor, however, it was irrelevant so it would not be considered).

255. Id. at 533 .

256. Fact Sheet, supra note 96. 
could also turn the all or nothing six-prong test into the primary beneficiary test as applied against an employer. Effectively, if a court believed that the employer received the primary benefit of the relationship, even if it was by the slimmest of subjective margins, then one of the six prongs would fail and an employment relationship would exist. The other five elements would be irrelevant. Once again, this would create a de facto primary beneficiary test rather than a six-element test. Employers would still have a hard time predicting how a court would determine if the internship was for the benefit of the intern. If the employer received even the slightest benefit from the relationship, the court might find that the internship experience was not for the benefit of the intern.

To address this problem, the DOL should change the second element to require that "the internship experience benefits the intern." This would change the second element from a subjective, unpredictable standard to a much more objective, predictable standard. Employers would know before they hired the intern what standard they would have to meet to satisfy the element. They would not have to worry about somehow failing to satisfy the element if they received any subjective benefit from the intern. They would simply have to ensure that the internship experience benefitted the intern, and that they also complied with the other five elements. By changing the standard from "for the benefit of" to "benefits," the second element still achieves its desired goal of making sure the intern receives a benefit from the internship, without undermining the other five elements. The concern that the employer may receive significant advantages at the intern's expense is addressed by the fourth "no immediate advantage" element.

The fourth element currently requires that "[t]he employer that provides the training derives no immediate advantage from the activities of the intern; and on occasion its operation may actually be impeded."257 The DOL should modify this element because it is unclear and does not sufficiently protect interns from being taken advantage of by employers. The most important goal of the intern standard is that it is clear, reliable, and predictable to all the parties in the relationship. "Immediate advantage" is an ambiguous and subjective term that is open to interpretation. To give clear meaning to this subjective term, the DOL should improve upon this element by drawing from language in their advisory letter to the American Bar Association concerning law students who work as unpaid interns on pro bono activities at for-profit law 
firms. $^{258}$ In the letter, the DOL explained that law firms that hire law students as unpaid interns will not derive any "immediate advantage" from the interns if the interns work only on pro bono matters that do not involve potential fee generating activities. ${ }^{259}$ The DOL further explained that "immediate advantage" also meant that interns could not participate in work that "free[ed] up staff resources for billable work that would otherwise be utilized for pro bono work."260

This concept of opportunity costs is not clear or obvious when someone considers what constitutes "immediate advantage," however, using an unpaid intern to avoid the opportunity costs of a paid employee performing pro bono work instead of income generating work confers a significant immediate advantage to the employer. If a law firm has committed itself to performing a certain amount of pro bono work every week, the time that the firm's paid attorneys and other employees spend working on that non-billable work is time they cannot spend generating revenue by working on billable work. By hiring an unpaid intern to perform the non-billable work, the firm's paid attorneys are freed up to work on billable work, and thereby generate revenues they would not have had the opportunity to generate if not for the intern. Therefore, even though the intern is performing non-billable work, the firm is still profiting off the intern, just as if the intern were performing billable work. The firm is gaining an "immediate advantage" from the intern's work.

This potential loophole in the fourth element should be closed by expressly stating what constitutes an "immediate advantage." The fourth element should be changed to, "the employer derives no immediate advantage from the intern's activities, meaning that the intern's activities do not: i) generate revenue or billable hours for the employer, ii) free up the employer or paid employees to work on revenue generating or more profitable activities, or iii) allow the employer to pursue any activities that the employer derives an advantage from, when the employer would not have pursued that activity, but for the activities of the intern."

This amended fourth element would clarify how an employer could gain an immediate advantage from an intern's activities. The first part of the amended fourth element addresses having the intern work on billable work. The second part addresses interns performing non-billable work that frees up employees to work on revenue generating activities. The

258. See ABA Intern Letter, supra note 125.

259. Id.

260. Id. 
third part is a broader, catch-all provision that is aimed at preventing employers from using interns for non-revenue generating activities that benefit the employer in some other way. This third part would encompass goodwill activities, which the employer would not have done had the employer not had access to the intern's free labor. An example of this would be if a company used unpaid interns to perform charitable work that would generate goodwill for the company in the public eye, but the company never previously intended to allocate paid resources (employees) to perform the charitable work. Overall, this amended fourth element creates a clear, predictable standard for employers and interns as to what "immediate advantage" means. It also prevents employers from taking advantage of unpaid interns by using them as revenue or goodwill generating human capital.

A regulatory provision that utilized the all or nothing six-prong test with amendments made to the second and fourth prong would be the best standard for the DOL to enact because it would provide a clear, predictable standard for determining when an intern is exempt from the FLSA.

2. An Amended Version of the All or Nothing Six-Prong Test Would Adhere to the Trainee Exception in Portland Terminal

The DOL should also enact an amended version of the all or nothing six-prong test because it would be consistent with the Supreme Court's trainee exception in Walling v. Portland Terminal Co. ${ }^{261}$ The petitioners in Portland Terminal were applicants for brakemen positions with the railroad, who had gone through a training program so they could be put on a list to be considered for hire. ${ }^{262}$ The petitioners were not paid minimum wage and brought a claim against the railroad alleging a violation of the FLSA. ${ }^{263}$ The Court held that the petitioners were not employees entitled to minimum wages because they were trainees exempt from the FLSA. ${ }^{264}$ This established the "trainee exception" under the FLSA - the same legal authority that excludes legally unpaid interns from the FLSA. ${ }^{265}$ Therefore, a regulation establishing an intern

\footnotetext{
261. 330 U.S. 148 (1947).

262. Id. at $149-50$.

263. Id. at 149 .

264. Id. at 153 .

265. See Xuedan Wang v. Hearst Corp., 293 F.R.D. 489, 492 (S.D.N.Y. 2013), mot. to certify appeal granted, 12 CV 793 HB, 2013 WL 3326650 (S.D.N.Y. June 27, 2013) (stating that although "intern" is not defined under the FLSA, the trainee exception from Portland Terminal provides the governing case law).
} 
exemption should be consistent with Portland Terminal's trainee exception. The amended all or nothing six-prong test is consistent with Portland Terminal's trainee exception because the Court in Portland Terminal used the same six prongs in its analysis and the Court did not expressly apply either an all or nothing or a totality of the circumstances approach to the six-prong test.

The first reason the amended version of the all or nothing six-prong test complies with the Portland Terminal trainee exception is because the Supreme Court used the same six prongs in its analysis. For the first prong, the Court acknowledged that the railroad trainees received the same kind of instruction at the railroad as they would have received had they "taken courses in railroading at a public or private vocational school ...."266 For the second prong, the Court noted that the railroad provided the trainees with training "free of charge" which "most greatly benefit[ed] the trainees." 267 For the third prong, the Court said the trainees' activities did "not displace any of the regular employees.",268 For the fourth prong, the Court found the railroad received "no "immediate advantage." 269 For the fifth prong, the Court discussed how trainees had to complete the training course to be "included in a list from which the company can draw when [the trainee's] services are needed," but that it was not guaranteed that the trainees on the list would be selected. ${ }^{270}$ For the sixth and final prong, the Court found that the railroad never "undertook [efforts] to pay" the trainees and "the trainees [never] expected to receive" any pay for their training. ${ }^{271}$

Looking at the DOL's six-prong test from Fact Sheet \#71, it is clear the DOL took their "six criteria" directly from Portland Terminal. ${ }^{272}$ If the second element and fourth element of the six-prong test were amended for clarity, those amended elements would still adhere to the Court's language in Portland Terminal. By changing the second element from "for the benefit of the intern" to "benefits the intern," the element still fits within the Court's consideration that the training "most greatly benefit[ed] the trainee." ${ }^{273}$ Nowhere does the Court say that the training must be solely for the benefit of the trainee. Furthermore, the phrase

\footnotetext{
266. Walling, 330 U.S. at $152-53$.

267. Id. at 153 .

268. Id. at 149-50.

269. Id. at 153 .

270. Id. at 150 .

271. Id.

272. See Fact Sheet, supra note 96.

273. Walling, 330 U.S. at 153.
} 
"most greatly" seems to acknowledge that the training may actually benefit the railroad by giving them a pool of qualified applicants to select from when work is needed. ${ }^{274}$ An amended second element would not contradict, and may actually more closely follow Portland Terminal's consideration of who benefitted from the trainee relationship. Additionally, amending the fourth element by clarifying what constitutes an "immediate advantage" would not contradict Portland Terminal's language, because the Court did not expound on immediate advantage, and the proposed amendments to the fourth element all clearly constitute an immediate advantage to the employer.

Courts that have interpreted Portland Terminal as adopting a primary beneficiary test rather than a six-prong test have misinterpreted Portland Terminal. In Solis v. Laurelbrook Sanitarium and School, Inc., ${ }^{275}$ the Sixth Circuit incorrectly interpreted Portland Terminal as having applied a primary beneficiary test. Solis based its support for the primary beneficiary test on Portland Terminal's finding that "the training 'most greatly benefit[ed]' the trainees" and "accepting the unchallenged findings . . . that the railroad receive no 'immediate advantage' from any work done by the trainees." 276 Solis interpreted the other five considerations as "various other facets of the relationship" but concluded that the ultimate decision rested upon "whether the trainees received the primary benefit of the work performed." 277 Solis' interpretation of the "most greatly benefit[ed]" language and "immediate advantage" language in Portland Terminal as creating a primary beneficiary test is misguided. If anything, the language in Portland Terminal created a two-part test or a no immediate advantage test, but it did not create a primary beneficiary test. Additionally, nowhere in the Portland Terminal decision does the Court say or even suggest that the trainee exception hinges on who receives the primary benefit of the relationship. The primary beneficiary interpretation of Portland Terminal is incorrect, and therefore the six-prong test adheres to Portland Terminal's trainee exception.

The all or nothing application of the amended six-prong test also adheres to Portland Terminal's trainee exception because it does not contradict Portland Terminal's application of the six-prongs of the test. The all or nothing application does not contradict Portland Terminal

274. Id.

275. 642 F.3d 518, 529 (6th Cir. 2011).

276. Id. at 526 (quoting Walling, 330 U.S. at 153).

277. Id. 
because Portland Terminal did not expressly apply an all or nothing or totality of the circumstances approach. While several courts have interpreted Portland Terminal as having adopted a totality of the circumstances approach, ${ }^{278}$ the fact remains that the Court did not say how or in what manner it was applying the six criteria. Therefore, while an all or nothing application of the amended six-prong test may not be expressly supported by Portland Terminal, it also does not expressly contradict Portland Terminal.

3. Enacting an Amended Version of the All or Nothing Six-Prong Test as a Regulatory Provision Would Give Sufficient Force to the Standard

While the amended all or nothing six-prong test is the proper test to apply to determine whether interns are exempt from the FLSA, the proper way to enact the test is for the DOL to enact it as a published regulation under section 29 of the Code of Federal Regulations. This regulation would create an exception for interns from the term employee under the FLSA. ${ }^{279}$ The DOL should enact the intern exception as a regulatory provision because it could enact the rule more quickly and easily than Congress could enact a statutory amendment and courts would still give high deference to the formal regulation.

Although they are not binding statutory law, formal regulations are usually given a high level of deference by courts. In Chevron, U.S.A., Inc. v. Natural Resources Defense Council, Inc., ${ }^{280}$ the Supreme Court established a two-step test for determining when a court should defer to an administrative agencies' regulatory interpretation of a statute. The first step under Chevron is "whether Congress has directly spoken to the precise question at issue. If the intent of Congress is clear, that is the end of the matter; because the court, as well as the agency, must give effect to the unambiguously expressed intent of Congress." ${ }^{281}$ If the regulation survives the first step, the second step is "if the statute is silent or

278. See, e.g., Reich v. Parker Fire Prot. Dist., 992 F.2d 1023, 1026 (10th Cir. 1993) ("there is nothing in Portland Terminal to support an 'all or nothing' approach); see also, Xuedan Wang v. Hearst Corp., 293 F.R.D. 489, 493 (S.D.N.Y. 2013), mot. to certify appeal granted, 12 CV 793 HB, 2013 WL 3326650 (S.D.N.Y. June 27, 2013) (stating that although "intern" is not defined under the FLSA, the trainee exception from Portland Terminal provides the governing case law; "I agree... that the Supreme Court in Walling looked to the totality of the circumstances of the training program).

279. 29 U.S.C. $\S 203(2012)$.

280. 467 U.S. 837 (1984).

281. Id. at $842-43$. 
ambiguous with respect to the specific issue, the question for the court is whether the agency's answer is based on a permissible construction of the statute." 282 For the second step, a reasonable approach to determining whether an agency's regulatory interpretation of a statute is permissible is to ask whether the interpretation is arbitrary and capricious. $^{283}$

Applying Chevron's two step analysis to the amended all or nothing six-prong test, the regulation would be interpreting the very ambiguous term employee under the FLSA. For the first step, the statute is ambiguous and Congress has not directly spoken to the precise question at issue, which is whether interns are exempt from the FLSA as nonemployees. Therefore, it would likely survive the first step. For the second step, the all or nothing six-prong test would likely be based on a permissible construction of the statute, because the Supreme Court constructed the statute similarly in Portland Terminal and Congress has not tried to change or enact a provision in the FLSA that would change Portland Terminal's trainee exception. Additionally, the amended sixprong test does not seem arbitrary or capricious because it is aimed at addressing a legitimate problem that has persisted for decades. Based on Chevron deference, an all or nothing six-prong regulation enacted by the DOL would almost certainly be given high deference by courts. Additionally, the intern exception could be enacted as a regulation much easier and much faster than as a statutory provision, which would sooner address the issue of uncertainty.

\section{B. Possible Effects the Regulatory Provision May Have on Internships}

If the DOL enacted a regulatory provision that established a clear, all or nothing six-prong standard to determine when an intern is an employee under the FLSA, it would likely affect internships and the job market in the United States. Four things would likely happen as a result of the regulatory provision. First, the regulatory provision would likely limit the amount of costly litigation over internships by providing parties with a tangible legal rule to comply with. Second, the regulatory provision would likely eliminate most clearly illegal internships. Third, the regulatory provision would likely save some legitimate internship programs that employers might have otherwise eliminated. Finally, the

282. Id. at 843 .

283. See Robert L. Glicksman \& Richard E. LeVy, Administrative LaW: Agency Action IN LEGAL CONTEXT 190. 
regulatory provision would likely lead to significant changes in how private sector internships are implemented and operated, which could lead to more job opportunities for low-income students. While the all or nothing six-prong regulatory provision would lead to some positive and negative consequences, overall, the regulatory provision would likely have a positive effect on employers, interns, internships, and the job market.

\section{Decrease Litigation}

An all or nothing six-prong regulatory provision would likely limit the amount of costly litigation involving internships. In the wake of Glatt and Wang, there has been a firestorm of lawsuits filed by former interns against their former employers. ${ }^{284}$ Courts have responded to the litigation by applying different, inconsistent standards to determine when an intern is an employee under the FLSA. $^{285}$ These inconsistent standards have failed to bring any legal certainty to the issue that might stem the tide of intern lawsuits. Additionally, these inconsistent standards have resulted in the possibility that the statute of limitations may be extended for intern claims in some cases; ${ }^{286}$ therefore, large class-action suits will likely linger in a state of uncertainty as long as the legal standard for internships remains unresolved. ${ }^{287}$

An all or nothing six-prong regulatory provision would establish a greater degree of certainty than currently exists. The proposed regulatory provision creates greater certainty by laying out six, easily understood elements that all must be met. Generally, more legal certainty leads to less litigation. This premise is supported by an empirical study done by Steven Scott Stephens in which Stephens found that sufficiently clear and predictable laws are not litigated as often as unclear, inefficient laws. ${ }^{288}$ Clear and predictable laws are not litigated

284. See, e.g., O’Neill v. E. Fla. Eye Inst., P.A., 11-CV-14384, 2012 WL 8969062 (S.D. Fla. Apr. 16, 2012), aff'd sub nom. Kaplan v. Code Blue Billing \& Coding, Inc., 504 F. App'x 831 (11th Cir. 2013), cert. denied 134 S. Ct. 618 (U.S. 2013); Kaplan v. Code_Blue Billing \& Coding, Inc., 504 F. App'x 831 (11th Cir. 2013), cert. denied, 134 S. Ct. 618 (U.S. 2013); Fraticelli v. MSG Holdings, L.P., 13 Civ. 6518, 2014 WL 1807105 (S.D.N.Y. May 7, 2014).

285. See supra Part II.B.3.

286. See Aly v. Butts Cnty., Ga., 841 F. Supp. 1199, 1202 (M.D. Ga. 1994) (stating that the FLSA's two-year statute of limitations may be equitably tolled if "a plaintiff... show[s] that the defendant made a misrepresentation for the purpose of inducing the plaintiff to delay filing suit and that the plaintiff actually and reasonably relied on the misrepresentation").

287. A law firm has even created a website encouraging unpaid interns to join in class-action suits. See UNPAID INTERNS LAWSUIT, http://unpaidinternslawsuit.com (last visited Nov. 24, 2014).

288. Steven Scott Stephens, The UnCERTAinty of LEgal Rights 89 (Stuart Bruchey ed., 
because people voluntary follow them. ${ }^{289}$ These efficient laws "settle[] disputes rather than caus[e] them." ${ }^{, 290}$ On the other hand, inefficient and unclear laws that lead to uncertain results are more heavily litigated because they are open to debate and the opportunity to be changed through interpretation. ${ }^{291}$ Furthermore, not only do inefficient laws lead to more lawsuits being filed, they also lead to lengthier, more expensive litigation. This occurs as a result of parties "fighting it out" over uncertain, inefficient laws. ${ }^{292}$ The greater the level of uncertainty, the greater the difference in parties' expectations of the outcome, and the more likely they will fight a case all the way to a judgment. ${ }^{293}$ Even riskadverse parties will fight a case to judgment if their difference in expectations of the outcome is great enough. ${ }^{294}$

In this instance, the trainee exception as it applies to interns is an inefficient law because it is unclear and unpredictable. Parties do not know which standard courts will apply to determine whether an intern is an employee; therefore, employers and interns expectations of how a court may rule on an intern's status under the FLSA may differ significantly. Both sides could look at the same fact pattern and each believe they have a ninety percent chance of winning. As a result of this significant difference in expectation of the law's application, both parties may expend an excessive amount of resources fighting their case through the extensive pre-trial discovery stage, trial stage, and possibly the appeals process. This consideration illustrates how inefficient the trainee exception law is, and how much economic waste its inefficiency is causing. As long as the law is unclear and unpredictable, heavy litigation will continue, regardless of how strong or frivolous a case may be. By establishing a clear, predictable all or nothing six-prong regulatory provision defining interns under the FLSA, the currently inefficient law will become much more efficient. This will help weed out frivolous claims from legitimate claims-preventing senseless, expensive litigation. Furthermore, it will provide employers and interns with an efficient law to guide their future conduct, which will limit the amount of legal claims in the future.

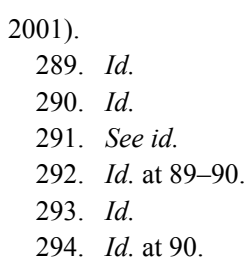


2. Reduce the Amount of Illegal Internships

An all or nothing six-prong regulatory provision will also eliminate a large number of illegal internships. This effect logically follows the first effect regarding litigation: "When a law is sufficiently clear and its application sufficiently predictable ... people voluntarily operate under it." 295 A clear, definite test for employers and interns stating what conditions an internship must meet for an intern to be exempt from the FLSA will remove much of the ambiguity that has led to illegal internships. While it will not eliminate all illegal internships, it will likely eliminate the significant portion of illegal internships that are the result of an employer's misinterpretation of the currently ambiguous requirements.

Limiting the number of illegal internships clearly benefits interns by preventing instances of employers taking advantage of interns by using them for free labor. It also benefits paid employees by eliminating a source of market place competition against which paid employees cannot compete-workers who work for nothing. Eliminating a large number of illegal internships should free up more paying, employee jobs that unpaid interns are currently taking off the job market. This will benefit prospective employees by creating more job openings and increasing prospective employee's bargaining power with employers. Freeing up paying jobs could also benefit the overall U.S. job market and may actually lower the unemployment rate.

While the benefits of limiting illegal internships are fairly obvious, there is also a downside associated with less illegal internship in the market place. An internship may be illegal without being evil or oppressive. For example, an intern may receive benefits from an internship outside of compensation or educational training. Many unpaid internships provide interns with the opportunity to meet people and establish important connections within their desired job field. A college student may be passionate about working in a certain lucrative industry, however, jobs the industry may be extremely difficult to obtain and may not be willing to pay an intern or take on the educational burden requirements of hiring an unpaid intern. The only way to enter the lucrative industry may be through an unpaid position. However, a regulatory provision may eliminate these opportunities for students because the unpaid positions would be clearly illegal, and therefore no longer exist, despite students' willingness to work without pay.

295. Id. at 89 . 
These types of unpaid internship positions are common in competitive industries like journalism and finance; ${ }^{296}$ however, they could disappear as result of a strict, clearly defined standard for legal unpaid internships. An intern cannot waive his or her minimum wage or maximum hour rights under the FLSA. ${ }^{297}$ Therefore, if an unpaid internship failed to meet all six of the requirements, it would be illegal, regardless of an intern's intentions or subjective benefits received from the position. The strict, all or nothing six-prong regulatory provision would likely eliminate several of these fringe internships because of the high standard it creates. While this may prevent abuse in some circumstances, it may also increase the barrier for students trying to break into their desired field.

\section{Preserve Legitimate Internships}

In addition to decreasing litigation and reducing the number of illegal internships, an all or nothing six-prong regulatory provision will likely save some legitimate, legal unpaid internship programs. In light of the recent litigation and legal uncertainty surrounding unpaid internships, some companies have simply cancelled their internship programs altogether. ${ }^{298}$ The legal uncertainty is discouraging all types of internships, ${ }^{299}$ both legal and illegal, and some legal internship programs will likely end as a result of the uncertainty. This is an unfortunate consequence because legal internships, paid or unpaid, provide significant benefits to both employers and interns. An all or nothing sixprong regulatory provision may provide employers with a high enough degree of legal certainty to prevent them from discontinuing their internship programs. This could effectively save several legitimate, legal internships that currently provide significant benefits to both employers and interns.

296. Jim Snyder \& Christie Smythe, Sleeping-Giant Issue of Unpaid U.S. Interns Gets Scrutiny, BLOOMBERG (June 26, 2013, 11:00 PM), http://www.bloomberg.com/news/2013-06-27/sleepinggiant-issue-of-unpaid-interns-gets-scrutiny.html.

297. See, e.g., Lynn's Food Stores, Inc. v. United States, 679 F.2d 1350, 1352 (11th Cir. 1982) (stating, "FLSA rights cannot be abridged by contract or otherwise waived because this would 'nullify the purposes' of the statute and thwart the legislative policies it was designed to effectuate." (citations omitted)).

298. Internship Litigation, supra note 9, at 7; see also Rachel Feintzeig \& Melissa Korn, Colleges, Employers Rethink Internship Policies, WALL ST. J. (April 22, 2014, 6:21 PM), http://online.wsj.com/news/articles/SB10001424052702304049904579517671151334870 (discussing how employers and colleges are rethinking internship programs).

299. Snyder \& Smythe, supra note 296 (referencing a quote from New York University law professor Samuel Estreicher). 
Internships benefit employers in ways other than simply providing cheap labor. One way employers benefit from internships is that the programs provide employers with a more work ready, experienced pool of job applicants. Employers are looking to hire employees that have experience working in a real-world setting. They are often hesitant to hire college graduates who do not have experience outside of the classroom. A 2010 survey by the Association of American Colleges and Universities found that " 73 percent of employers stated the desire for higher education to put more emphasis on 'the ability to apply knowledge and skills to real-world settings through internships and other hands-on experiences." "300 Internships are one of the best ways for college students to receive real-world knowledge and skills before entering the job market. Employers also benefit from internships because they help employers identify talent that will be a good organizational fit within a company. ${ }^{301}$ Studies show that employee retention rate is higher for employees who have previously interned with a company, as opposed to employees who did not previously intern with a company. ${ }^{302}$ Thus, internships give employers a way of identifying talented employees who fit well with their company, while also minimizing turnover costs.

The benefits received from internships are not a one-way street. Interns also receive significant benefits from their internships, regardless of whether they are paid or unpaid. Internships provide interns with experience and real-world skills that make them more employable and increase their likelihood of finding full-time employment. When evaluating job candidates, employers are beginning to expect some type of internship experience. Internships have become increasingly prevalent among college students ${ }^{303}$ as employers look for applicants with work experience outside of the classroom. ${ }^{304}$ Real-world experience can be difficult for college students to obtain. Internships provide a way for college graduates to bridge the experience gap between the classroom

300. Charles Westerberg \& Carol Wickersham, Internships Have Value, Whether or Not Students Are Paid, Chron. Highr EduC. (Apr. 24, 2011), http://chronicle.com/article/Intern ships-Have-Value/127231/.

301. Jacquelyn Smith, Internship Wish List: The 12 Things Students Value Most, FORBES (Jan. 8, 2014, 12:30 PM), http://www.forbes.com/sites/jacquelynsmith/2014/01/08/internship-wish-list-the12-things-students-value-most/.

302. Id.

303. A survey by the National Association of Colleges and Employers found that "more than 63 percent of graduating seniors in 2013" had some form of an internship-like experience. Snyder \& Smythe, supra note 296. Of the students with internship experience, about 48 percent of the internships were unpaid. See id.

304. Westerberg \& Wickersham, supra note 300. 
and the workplace. Statistics support this proposition, as a recent study conducted through the career services office at Southwestern University found that students who completed one internship while in school were " 13 percent more likely to find full-time employment over those that did not." 305

In addition to providing college students with workplace experience, internships also provide students with a way to figure out what type of work they enjoy and where they want to work. Similar to the benefit employers receive from finding job candidates that are a good fit within their organization, students can also use internships as a way to "test drive" a company to see if it is somewhere they would like to work fulltime. The Southwestern University study also found that students who completed an internship were happier with their job outcomes than students who did not complete an internship, which could be attributed to the interns finding an occupation they enjoyed before committing to it. ${ }^{306}$

\section{Increase Job Opportunities for Low-Income Students}

An all or nothing six-prong regulatory provision would also likely lead to significant changes in how private sector, for-profit internships are structured. By requiring employers to meet the high standard established by the all or nothing six-prong test, employers who previously hired unpaid interns might decide to simply pay interns rather than worry about complying with the provision. If the regulatory provision led to more paid internships, it could lead to more internship opportunities for low-income students. Conversely, if the regulatory provision caused a net decrease in the overall number of internships in the private sector, third parties might increase funding for internship programs.

The all or nothing six-prong regulatory provision may lead to more paid internships in the private sector. Under the proposed standard, employers would have to meet six objective requirements to ensure they are complying with the law. This would impose a much greater compliance burden on employers than the less stringent primary beneficiary test or the totality of the circumstances test. To comply with this standard, employers would have to implement expensive oversight and compliance measures. Furthermore, the time and effort an employer

305. Brooke Chatterton, What Job Statistics Say About the Value of College Internships, HUFFINGTON POST (July 27, 2014, 5:59 AM), http://www.huffingtonpost.com/southwesternuniversity/what-job-statistics-say-a_b_5399641.html.

306. Id. 
would expend trying to create an "educational environment" that "benefits the intern" could create efficiency costs for employers that limit the productivity of the employers' staff. Employers may conclude that the significant costs of complying with an unpaid internship outweigh the costs of paying interns a minimum wage salary. Employers may also consider the minimum wage costs to be insignificant when compared to the substantial long-term benefits employers receive from hiring interns, such as identifying talented job candidates and reducing turnover. ${ }^{307}$ These considerations could incentivize employers to pay interns a minimum wage instead of hiring unpaid interns or discontinuing internship programs.

If the proposed regulatory provision led to more paid internships, it would likely increase the amount of internship opportunities for lowincome students. One of the major criticisms of unpaid internships is that they disproportionately favor the wealthy. ${ }^{308}$ Students who come from high-income families have the financial resources to work as an unpaid intern, whereas low-income students do not have the financial resources necessary to work for no pay and still support themselves. ${ }^{309}$ Consequently, unpaid internships provide high-income students with more opportunities and easier access to the job market than low-income students. Therefore, unpaid internships perpetuate the economic divide between the haves and the have-nots by "provid[ing] people who already have a leg up a way to get the other leg up." "310

A regulatory provision that effectively increases the number of paid internships and decreases the number of unpaid internships could help close this socioeconomic gap. By converting unpaid internships into paid internships, low-income students could afford to take intern positions that they otherwise could not. This would create more opportunities for low-income students to enter the job market. It would also provide low-income students with more opportunities to receive the experience and real-world training employers look for in job candidates. ${ }^{311}$ This would benefit low-income students, but it would also benefit employers. Giving low-income students more access to the job

307. See supra Part III.B.3.

308. Kimberlee McTorry, Death of Unpaid Internships, The Rise of Social Equality: Legality of Unpaid Internships Under the Fair Labor Standards Act, 8 S.J. POL'Y \& JUST. L.J. 47, 58-59 (2014).

309. Id. at 59 .

310. David Carr, Overlook the Value of Interns at Great Peril, N.Y. TIMES (Nov. 24, 2013), http://www.nytimes.com/2013/11/25/business/media/overlook-the-value-of-interns-at-greatperil.html?pagewanted $=$ all\&_r $=0$.

311. See supra Part III.B.3. 
market would allow employers to choose from a larger pool of talented candidates. Employers could base their hires more on a candidate's merits and qualifications rather than candidate's ability to work for no pay. This does not suggest that the availability of more paid internships will put an end to economic inequality in regards to job market opportunities, however, it may help close the gap.

While the proposed regulatory provision may cause some employers to convert their unpaid internships into paid internships, other employers may choose to discontinue their unpaid internships altogether. As a result, the provision may have a net effect of decreasing the total amount of paid and unpaid internships available to students. In this event, internship programs may see an increase in funding from third parties. Universities are already taking an active role in funding internships. Jobplacement rates are a powerful statistic that competing universities use to justify their rising tuition costs. ${ }^{312}$ Because internships lead to jobs, some universities have begun providing stipends for students to work as unpaid interns at for-profit enterprises. ${ }^{313}$ A regulatory provision that decreases the amount of available internships will likely encourage universities to allocate more funds towards these artificially created internships in an effort to get their students hired and stay ahead of the competition. States have also begun providing subsidies for internships with for-profit companies through their state schools. The Ohio Board of Regents recently distributed nearly $\$ 11$ million dollars to colleges, universities, and technical centers throughout the state in an effort to subsidize intern wages in high demand industries. ${ }^{314}$ Additionally, some have proposed that federal funds be allocated towards internships though federal student loan programs ${ }^{315}$ or subsidies for low-income students. ${ }^{316}$

All of this points to a growing trend toward subsidizing internships in an effort to promote job placement and skill training. A regulatory provision imposing a high standard for unpaid internships will increase

312. Melissa Korn, Unpaid Internships? Some Colleges Pick Up the Tab, Wall ST. J. (June 19, 2013, 2:29 AM), http://online.wsj.com/news/articles/SB1000142412788732383650457855363092 2908800.

313. Id. These stipends for unpaid internships at for-profit companies raise the legal question of whether universities may be funding illegal unpaid internships. Id.

314. Amy Hansen, Grant Aims to Increase Internships Across the State, STATEImPACT (Mar. 20, 2014, 5:00 PM), http://stateimpact.npr.org/ohio/2014/03/20/grant-aims-to-increase-internshipsacross-the-state.

315. Edward L. Glaeser, High Value in Unpaid Internships, Bos. GloBE (Oct. 31, 2013), http://www.bostonglobe.com/opinion/2013/10/30/unpaid-internships-unpopular-solution-realproblem/KqHbPLxfgdjuhcVN0xL6XJ/story.html.

316. McTorry, supra note 308 , at $60-61$. 
the incentives for third parties to fund internships because the provision will likely decrease the amount of unpaid internships in the market, thereby creating a need for more paid internships to fill the gap.

\section{CONCLUSION}

A large number of high-profile lawsuits have highlighted the problem of abusive, illegal internships in the private sector. While illegal internships are a serious problem, the source of this problem has been legal uncertainty. For decades, the United States legal system failed to establish any legal boundaries for internships and now its court system is reaping the consequences. Congress has failed to provide any answers to resolve the uncertainty. Courts have tried to provide answers, but they cannot agree on any consistent legal standards. Therefore, the DOL should provide an answer by enacting a regulatory provision that creates a clear standard to determine what constitutes an illegal unpaid internship under the FLSA. If the DOL enacted a regulatory provision, it would address the problem of uncertainty surrounding illegal unpaid internships and likely have a positive effect on the U.S. job market. However, until someone addresses the uncertainty by establishing a clear and uniform standard, the problem of unpaid internships, and the costs associated with it, will continue to plague employment law in America. 